\author{
Universidade de São Paulo \\ Faculdade de Filosofia, Ciências e Letras \\ Departamento de Educação, Informação e Comunicação \\ Programa de Pós-Graduação em Educação
}

Dayana Coelho Souza

OS DISCURSOS SOBRE LAÇOS DE FAMÍLIA E ESCOLA: O QUE OS ESTUDANTES TÊM A DIZER ?

Ribeirão Preto

2019 
DAYANA COELHO SOUZA

\title{
OS DISCURSOS SOBRE LAÇOS DE FAMÍLIA E ESCOLA: OS QUE OS ESTUDANTES TÊM A DIZER?
}

\author{
Dissertação apresentada ao Programa \\ de Pós-Graduação em Educação da \\ Faculdade de Filosofia Ciências e \\ Letras de Ribeirão Preto- FFCLRP, da \\ Universidade de São Paulo- USP, para \\ obtenção do título de Mestre em \\ Educação. \\ Área de Concentração: Educação \\ Orientadora: Profa. Dra. Filomena \\ Elaine Paiva Assolini \\ Versão corrigida
}

Ribeirão Preto 
Autorizo a reprodução e divulgação total ou parcial deste trabalho, por qualquer meio convencional ou eletrônico, para fins de estudos e pesquisas, desde que citada a fonte.

\section{FICHA CATALOGRÁFICA}

Souza, Dayana Coelho

Os discursos sobre laços de família e escola: o que os estudantes têm a dizer? Ribeirão Preto, 2019. 96 p. : il. $30 \mathrm{~cm}$ Dissertação de Mestrado, apresentada à Faculdade de Filosofia Ciências e Letras de Ribeirão Preto/USP. Área de concentração: Educação.

Orientadora: Assolini, Filomena Elaine Paiva.

1. Famílias. 2. Psicanálise. 3. Adolescência. 4. Análise de discurso. 
SOUZA, D.C. Os discursos sobre laços de família e escola: o que os estudantes têm a dizer? 2019. 96f. Dissertação (Mestrado em Educação) - Faculdade de Filosofia, Ciências e Letras de Ribeirão Preto -FFCLRP, da Universidade de São Paulo, Ribeirão Preto, 2019.

Aprovado em:

Banca Examinadora

Profa. Dra. Instituição:

Julgamento: Assinatura:

Profa. Dra. Instituição:

Julgamento: Assinatura:

Profa. Dra. Instituição:

Julgamento: Assinatura: 


\section{AGRADECIMENTOS}

Agradeço ao meu companheiro Ricardo por todo apoio e amor nessa fase de estudos.

À minha mãe Luzia, que transmitiu a garra, desejo de saber e possibilidades de ir além das questões sociais postas.

À minha tia avó Enide por ocupar um lugar de cuidados para que minha mãe pudesse trabalhar e garantir o sustento de nossa família.

À minha irmã Olga e sobrinha Paloma que também compuseram minha família e minhas origens.

À Professora Elaine Assolini, por ter acolhido meu desejo de saber sobre as famílias e a psicanálise, e estar me orientando neste percurso.

À Professora Leda Tfouni por ter aberto o caminho para minha inserção no mestrado.

À escola e adolescentes que propiciaram que este trabalho se desenvolvesse.

À minha analista que acolhe meus anseios e desejo de ocupar o lugar de escuta.

Aos amigos e colegas que me constituem nas relações horizontais.

E às minhas queridas cachorrinhas, parceiras de todas as horas. 


\section{NOVOS AGRADECIMENTOS}

Agradeço ao professores e professoras que de algum modo me marcaram positivamente.

Agradeço aos integrantes da banca de qualificação que trouxeram um olhar externo, professores: Carlos Eduardo Leal e Miguel Bairrão. 
SOUZA, D.C. Os discursos sobre laços de família e escola: o que os estudantes têm a dizer? 2019. 96f. Dissertação (Mestrado em Educação) - Faculdade de Filosofia, Ciências e Letras de Ribeirão Preto - FFCLRP, da Universidade de São Paulo, Ribeirão Preto, 2019.

\section{RESUMO}

A presente dissertação foi elaborada a partir de pesquisa na área da educação, embasada na psicanálise freudo-lacaniana e com contribuições da Análise de Discurso de matriz francesa pecheuxtiana. Para Lacan (2008) a função primordial da família é transmissão da cultura através da inserção no universo da linguagem, Roudinesco (2003) ressaltou que a principal lei a ser transmitida é a do desejo que funda os sujeitos e permite a civilização. Nosso objetivo geral foi analisar os discursos que estudantes adolescentes apresentam sobre laços de família e educação formal. Já nossos objetivos específicos foram os seguintes: Analisar as concepções sobre família nos discursos de adolescentes; Analisar como discursos sobre laços de família atravessam os discursos sobre a educação formal; Analisar os lugares ocupados pela família e pela escola na transmissão da lei. Para isso, efetuamos análise do discurso de quatro adolescentes, com idades variando entre treze e quatorze anos que frequentam oitavo e nono ano do ensino fundamental II, de uma escola pública no interior paulista. Foram efetuadas entrevistas a partir de roteiro pré-elaborado sobre o tema com questões abertas baseadas na literatura pesquisada sobre o assunto, e elaboradas de modo que encorajassem os sujeitos a narrarem as suas histórias familiares, a conceituarem família, a discorrerem sobre o que pensam sobre a família na atualidade e a relação com a educação formal. Posteriormente as entrevistas foram gravadas e transcritas. Foram efetuadas escutas flutuantes dos áudios e leituras flutuantes das entrevistas transcritas e selecionados recortes das entrevistas, tendo como critério os objetivos da pesquisa. Os adolescentes escutados nos ensinaram que as subjetivações não são determinadas a algum tipo de arranjo familiar específico, e sim em como eles se posicionaram frente às contingências de suas famílias, a partir do que foi transmitido para eles. O lugar do Outro esteve presente nos discursos dos adolescentes escutados, de modo que não estavam em uma posição de errância. Os discursos apresentaram famílias nas quais houve relações de menor autoritarismo, são outros modos de se relacionar, mas há interdição presente. A escola ocupou lugar de referência para as identificações imaginárias, simbólicas e lugar de amenizar as angústias. Já atividade 
intelectual apareceu como objeto necessário a uma possível completude no futuro, mas não como uma atividade prazerora, sublimatória.

Palavras chaves: Famílias. Psicanálise. Adolescência. Análise de discurso. 


\section{ABSTRACT}

The present work is elaborated from a research in the education field, based on FreudianLacanian pshychoanalysis with contributions from pecheuxtian discourse-analysis theory. To Lacan (2008) the main duty of a Family is culture transmission through insertion into the language universe, Roudinesco (2003) pointed that the main law to be transmitted is the law of desire that creates the subjects and allows civilization. Our general goal is to analyze the speeches that adolescent students, present about Family ties in current days and about formal education. Our specifics goals are as follows: Analyze the concepts about Family in the speeches; Analyze how the speeches about Family ties meet the speeches about formal education; Analyze the places occupied by the Family and by the school in the transmission of the law; To do so we analyzed four interviews made with adolescents ages ranging from thirteen to fourteen years cursing the eightieth and ninetieth grade from a public school in the inner state of São Paulo. Interviews were performed following a preestablished route about the theme with open questions based on the literature researched about them, elaborated in a way that encourages the subjects to narrate their Family stories, to concept Family, to discuss about what they think of the Family in current days and the relation with formal education. Later the interviews were taped and transcribed. Flutuant audio listening and Reading the transcribed interviews were made and cuts from interviews were selected, having as criteria the goals of the researches. Significant chain analysis has been performed where the subject appeared through indications. From this we point that listened adolescents tought us that the subjetivations are not determined to the specific Family ties but in how they positioned themselves facing their families' contingencies, from what were taught to them. This way, the family position as the Other was present in the narratives listened, even if solely to contest them. The narratives presented families in networks (ROUDINESCO, 2003) in which horizontal relations were emphasized. Those are other ways of relationing, but interdiction is present, although of the predomination of horizontality. School takes a place of reference to the imaginary identifications and the place of softening the angst. The intelctual activity showed as an object necessary to a possible completion in future but not as a pleasurable activity, sublimation.

Keywords: Family. Pshychoanalysis. Adolescence. Discourse-analysis 
LISTA DE ABREVIATURAS E SIGLAS

Análise do Discurso $\quad$ AD

Comitê de Ética e Pesquisa $\quad$ CEP

Faculdade de Filosofia, Ciências e Letras de Ribeirão Preto $\quad$ FFCLRP

Termo de Consentimento Livre e Esclarecido $\quad$ TCLE

$\begin{array}{ll}\text { Termo de Assentimento } & \text { TA }\end{array}$ 


\section{SUMÁRIO}

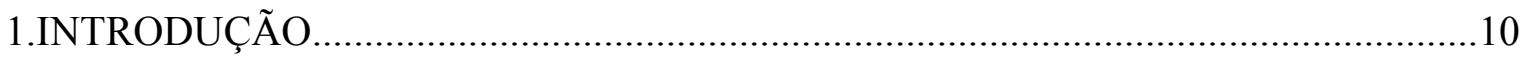

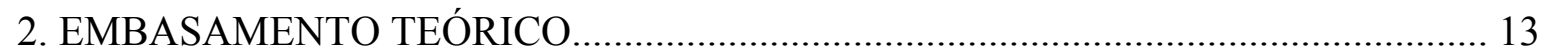

2.1 Contribuições da Análise do discurso e aproximações com a psicanálise

2.2. $\quad$ Preceitos $\quad$ básicos $\quad$ do $\quad$ pensamento psicanalítico

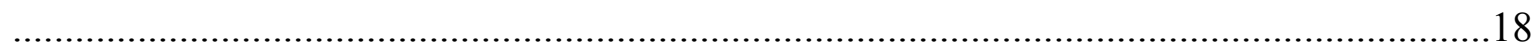

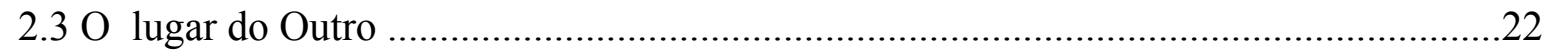

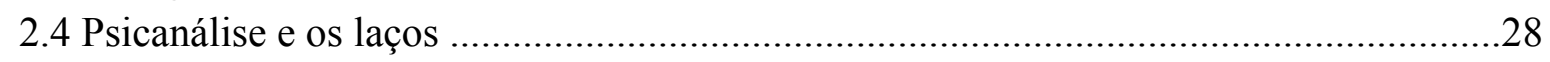

2.5 Psicanálise e contribuições para o educar .......................................................................

3.FAMÍLIA: ASPECTOS HISTÓRICOS E

3.1 Família: da idade média à modernidade

3.2 Um olhar contemporâneo para a família ................................................................... 38

4.LAÇOS DE FAMÍLIA E

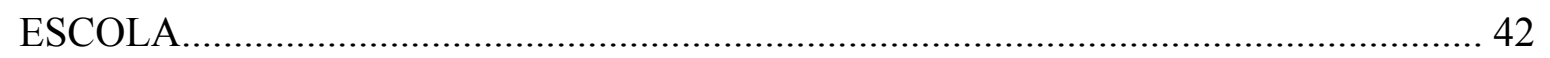

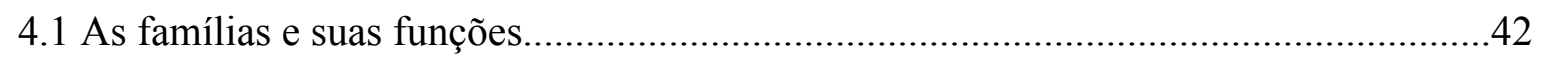

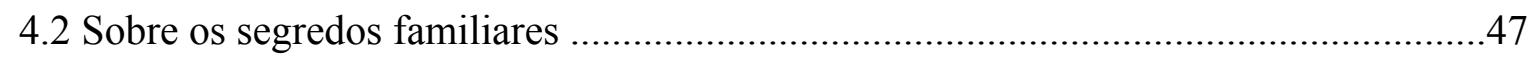

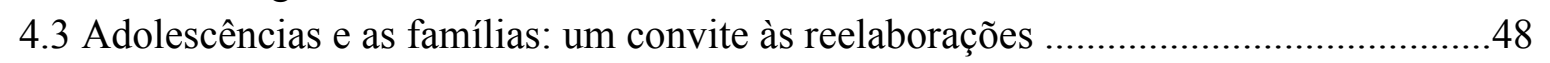

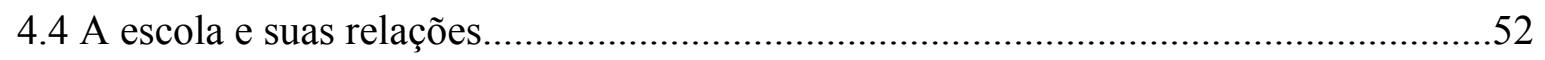

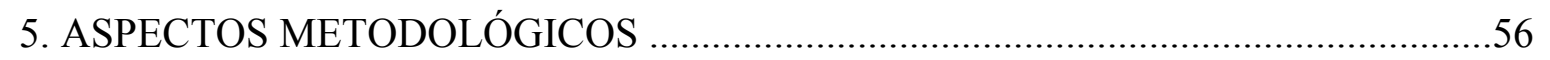

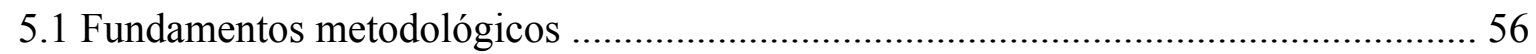

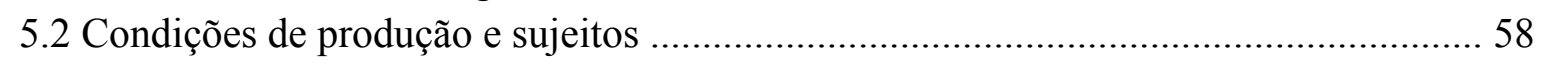

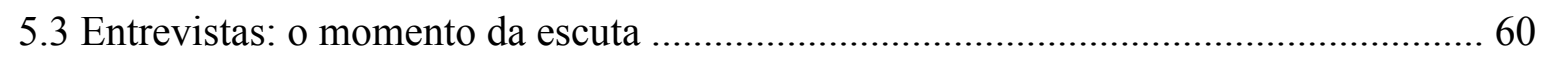

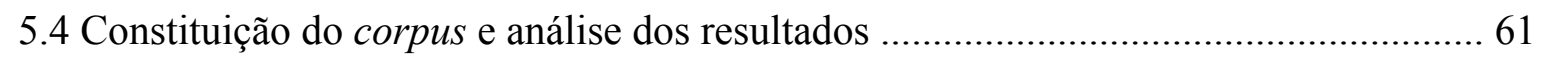

6. O QUE OS ADOLESCENTES ESCUTADOS FALAM SOBRE FAMÍIAS? .............63

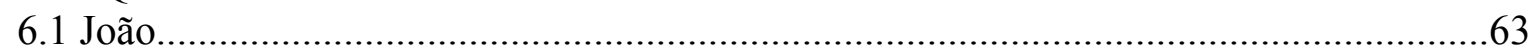

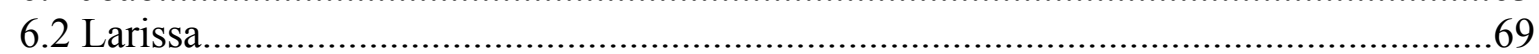

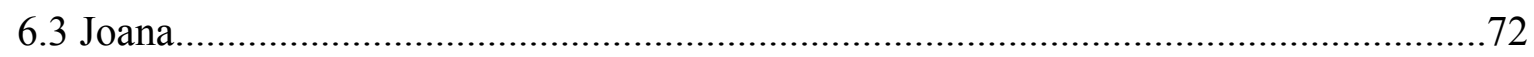

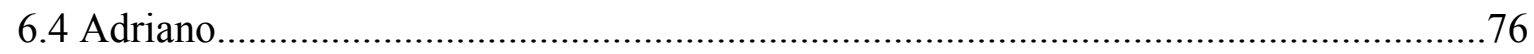

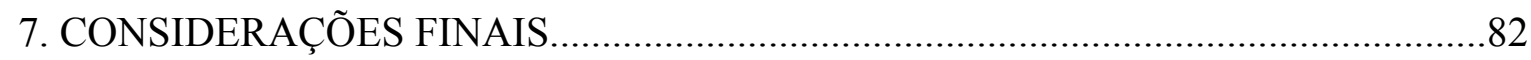

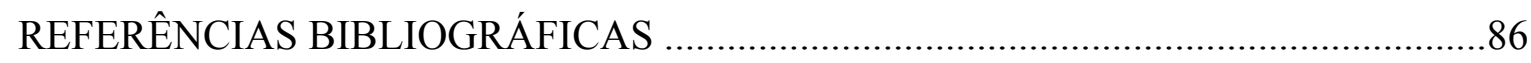

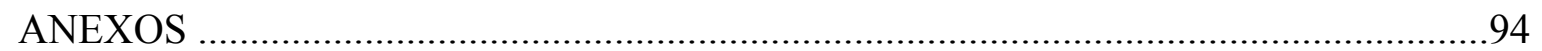




\section{INTRODUÇÃO}

$\mathrm{Na}$ realidade ele não tinha vontade de iniciar uma conversa premente que terminasse em soluções. Um pouco da mortificação do jantar da véspera sobre mesadas, com o pai misturando autoridade e compreensão e a mãe misturando compreensão e princípios básicos - um pouco da mortificação da véspera pedia, no entanto, prosseguimento. Só que era inútil procurar em si a urgência de ontem. Cada noite o sono parecia responder a todas as suas necessidades. E de manhã, ao contrário dos adultos que acordam escuros e barbados, ele despertava cada vez mais imberbe. Despenteado, mas diferente da desordem do pai, a quem parecia terem acontecido coisas durante a noite. Também sua mãe saía do quarto um pouco desfeita e ainda sonhadora, como se a amargura do sono tivesse lhe dado satisfação. Até tomarem café todos estavam irritados ou pensativos, inclusive a empregada. Não era esse o momento de pedir coisas. Mas para ele era uma necessidade pacífica a de estabelecer domínios de manhã: cada vez que acordava era como se precisasse recuperar os dias anteriores. Tanto o sono cortava suas amarras, todas as noites. (LISPECTOR, 1998, p. 54)

Iniciamos nosso trabalho com a citação de Clarice Lispector (1998), trata-se de trecho de um conto intitulado Começos de uma fortuna que está na obra Laços de família (1998). O trecho demonstra um fluxo de pensamentos de um adolescente sobre a relação com sua família e foi apresentada para ilustrar e nos aproximar da questão a ser apresentada, visto que a arte nos representa de modo legítimo.

Sendo assim, iniciamos informando que o presente trabalho se trata de uma dissertação elaborada a partir de pesquisa na área da educação com o tema envolvendo educação, família e escola. Escutamos o que os adolescentes discursaram e assim produzimos nosso trabalho a partir de seus dizeres e da literatura.

O desejo de saber sobre a família surgiu a partir da prática profissional como psicóloga na área sociojurídica, em que circulavam diversos discursos sobre famílias entendidas como famílias conjugais e heterossexuais. 
Poderes familiares, o direito ao exercício da tutela e cuidados das crianças, eram suspensos ou rompidos tendo como argumento o fato de determinados arranjos familiares não corresponderem ao que o discurso jurídico afirmava ser família.

Assim, ancorado nesse desejo de saber sobre as famílias e sobre a psicanálise, buscava-se textos acadêmicos sobre o assunto e o que encontrava eram textos sobre educação, que enfatizavam os aspectos de funções parentais em detrimento de figuras parentais (BERNARDINO; KUPFER, 2008).

Desse modo, o projeto de pesquisa foi elaborado em articulação com a área da educação e de modo que os sujeitos participantes fossem adolescentes visto que Briole (1994) mencionou que os discursos dos adolescentes são os discursos de sua época, assim entendemos que seus dizeres, a partir de suas singularidades, forneceram- nos indícios dos discursos sobre laços familiares de nossa época.

Além disso, a escolha da psicanálise como fundamentação foi efetuada porque elas pretendem ultrapassar a dicotomia indivíduo-sociedade e apresentou hipóteses de influências mútuas (ROSA; DOMINGUES, 2010). Assim sendo, entendemos que a escuta da particularidades dos adolescentes nos ofereceu indícios referentes à sociedade

Portanto, foi proposta a presente pesquisa com adolescentes em articulação com o campo da educação. Nosso objetivo geral foi analisar os discursos que estudantes adolescentes apresentam sobre laços de família e educação formal. Já nossos objetivos específicos foram os seguintes: Analisar as concepções sobre família nos discursos de adolescentes; Analisar como discursos sobre laços de família atravessam os discursos sobre a educação formal; Analisar os lugares ocupados pela família e pela escola na transmissão da lei.

No decorrer das escutas, os objetivos foram desdobrados e entendemos que o que chamamos de concepção não corresponde a um saber referencial sobre o tema, ou identificar qual arranjos eles consideram o mais adequado, mas sim o que disseram a partir do significante família, visto que:

... para a psicanálise a família, seja qual for sua evolução, e sejam quais forem as estruturas às quais se liga, será sempre uma história de família, uma cena de família, semelhante àquela dos Labdácidas, dos reis shakespearianos ou dos irmãos Karamázov. A família, no sentido freudiano, põe em cena homens, mulheres e crianças que agem inconscientemente como heróis trágicos e criminosos. Nascidos condenados, eles se desejam, se dilaceram ou se matam, e não descobrem a redenção senão ao preço de sublimar as pulsões. (ROUDINESCO, 2003, p. 129). 
Sobre como os discursos atravessaram os discursos sobre educação formal, escutamos em que lugar os adolescentes colocam a escola e família, quais endereçamentos são efetuados e interpretamos sobre a transmissão da cultura, ou seja, o próprio processo de civilizar desses adolescentes.

Tendo isso em vista, assinalamos que no capítulo dois, Embasamento téorico, situamos e discorremos a respeito de embasamento teórico, a saber: psicanálise freudolacaniana além de contribuições da análise de discurso (AD) pecheuxtiana. Nele mobilizamos os conceitos de discurso e a noção de sujeito, bem como os articulamos com outras noções basilares que entendemos serem imprescindíveis para a nossa pesquisa.

Quanto ao capítulo três, Família: aspectos históricos e sociais, o próprio título já refere sobre o que será trabalhado. Já no capítulo quatro, Laços de família e escola, mobilizamos questões presentes na literatura psicanalítica sobre família e educação, bem como a escola enquanto espaço de saber e de relações.

No capítulo cinco, Aspectos metodológicos, tratamos de nossas questões metodológicas, as quais tivemos a psicanálise como posição e com importantes contribuições da $\mathrm{AD}$ pecheuxtiana.

O capítulo seis, $O$ que os adolescentes escutados falam sobre família, traz as análises dos discursos dos adolescentes que foram apresentados no um a um e nomeados, naturalmente com nomes fictícios, de modo a manter as particularidades que são tão caras à psicanálise.

Finalmente, o capítulo sete contém as Considerações finais, ressaltando que não se trata de um encerramento do tema. Para além disso, buscamos responder aos nossos questionamentos, mas também ofertar abertura para outros questionamentos.

Sendo assim, prosseguimos com nosso trabalho. 


\section{EMBASAMENTO TEÓRICO}

Assim como já mencionamos brevemente na introdução, nossa pesquisa foi elaborada a partir da psicanálise freudo-lacaniana com contribuições da Análise de Discurso (AD) de matriz teórica francesa pecheuxtiana.

A escolha da psicanálise foi realizada devido ao aprofundamento que apresenta sobre os fenômenos e rompimento com um dualismo entre mente e corpo, além do olhar aprofundado aos aspectos da civilização humana de modo a romper com visões que não consideram os sujeitos em sua singularidade.

A contribuição da $\mathrm{AD}$ ocorreu devido ao conceito de discurso que diz respeito aos efeitos de sentidos entre interlocutores (PECHEAUX, 2015) e aos conceitos de recorte e sequência discursiva (COURTINE, 1981 apud ASSOLINI; DORNELAS, 2016) que apresentaremos com mais vagar no capítulo Aspectos metodológicos e que nos foram essenciais para o entrelaçamento da pesquisa em psicanálise em um contexto acadêmico.

Tendo isso em vista, a partir de então vamos movimentar os conceitos e noções básicas da teoria psicanalítica e as contribuições da $\mathrm{AD}$ pecheuxtiana.

\subsection{Contribuições da Análise do discurso e aproximações com a psicanálise}

Iniciamos destacando que nossos objetivos são de analisar os discursos de adolescentes, sendo assim, começaremos por mobilizar o que seja discurso e noção de sujeito.

Para isso, faz-se imprescindível destacar a pecualiridade humana de estar inserida na linguagem e destacamos que esta é algo diferente da comunicação que ocorre entre outros animais. Elia (2010) ressaltou que a linguagem é uma produção expressiva, ampla e própria do ser humano, em suas palavras:

Toda produção do campo do sentido é da ordem simbólica, seja falada ou não. Um gesto, uma expressão do rosto, do corpo, uma dança, um desenho, tanto quanto uma narrativa oral, serão produções simbólicas, regidas pelo significante, e assim, ditas verbais, por estarem na dependência do verbo significante, e não serem expressas por via oral. Não existirá, portanto o "não-verbal" no campo simbólico, e menos ainda o "pré-verbal". O domínio do verbal não é uma conquista do desenvolvimento cognitivo ou simbólico, mas uma condição inerente ao falante como tal. Como ser de linguagem, o sujeito se constitui no domínio do verbal. Trata-se de um domínio no sentido de um campo, um 
território, um universo, que contém e subsume o sujeito, mais do que um domínio de uma função, isto é, de algo que o sujeito pode dominar ou não. (ELIA, p. 2010, p.21)

Então, trabalhamos com o pressuposto de que a linguagem é própria do humano e para além de uma função comunicativa. O linguista Saussure (1980, apud DOR, 1989), ao estudar a linguagem humana, postulou um corte entre língua e fala. A primeira foi postulada como um código que é compartilhado socialmente, enquanto a fala diz respeito ao aspecto individual.

Complementamos a ideia com Dunker, Paulon e Milán-Ramos (2017) que destacaram que a língua se aproxima de um ideal e a fala diz respeito a uma instância subjetiva. Portanto, linguagem, língua e fala são interligadas mas não se tratam de um mesmo conceito.

Saussure (2005, apud LAUREANO, 2008) nos ensinou o que é um signo a partir da ideia de uma moeda, imaginamos o signo composto de um lado pelo significante, ou seja, o aspecto concreto material (no caso da palavra o som, imagem acústica) e o significado como o conceito socialmente partilhado. Esse postulado foi adaptado pelo pensamento lacaniano para se pensar o inconsciente, trabalhamos com mais vagar essa questão no decorrer deste trabalho.

Tendo situada a noção de linguagem, língua e fala, prosseguiremos para a noção de discurso, objeto de estudo do nosso trabalho. Dunker, Paulon e Milán-Ramos (2017) afirmaram que o enlace entre a psicanálise lacaniana e $\mathrm{AD}$ pecheuxtiana se dá por meio da noção de discurso visto que nas duas teorias o discurso não é uma unidade, não há confluência entre enunciado e enunciação (entre o que se acredita ter dito e o que foi dito). Assim, Assolini (2003) destacou que estudar o discurso não corresponde a estudar seu conteúdo e sim seu funcionamento.

Outro aspecto a ser destacado é a heterogeneidade discursiva, ou seja, o discurso é atravessado por muito outros discursos, sendo assim, podemos encontrar um mesmo termo realizando várias funções e satisfazendo diferentes interesses (DUNKER; PAULON; MILÁN-RAMOS, 2017).

No pensamento lacaniano, o discurso corresponde a um laço social que vai além de somatórias de falas individuais, trata-se de uma condição para um conjunto de enunciados possíveis, cada material discursivo é uma composição de elementos que comportam a emergência do sujeito. (DUNKER; PAULON; MILÁN-RAMOS, 2017). 
Além disso, complementamos a ideia com Pereira (2005) que ressaltou ser o discurso também "decantado e sedimentado pela história" (PEREIRA, 2005, p. 105).

Horne (2007) ressaltou que, no pensamento lacaniano, o discurso foi pensado enquanto um algorítimo contendo quatro lugares, a saber: $\mathrm{O}$ do agente, do outro, da verdade e da produção. Sendo representado do seguinte modo:

\section{Agente $\quad \underline{\text { O Outro }}$ \\ Verdade A produção}

Há quatro elementos que giram, alteram seus lugares, de modo a determinar quatro discursos que são: discurso do mestre, da universidade, do analista e da histérica. Vale citar que:

O sujeito, representado por um significante, dirige-se ao Saber no lugar do Outro. Estabelece-se o discurso do Mestre. Se o sujeito se dirige ao saber médico, o médico responderá desde o lugar de saber - e tomara que saiba! Se ele dirige ao analista, este não responde como saber. Se deixa cair no lugar em que está o que não se diz, a opacidade do discurso, para começar o giro em direção ao discurso da histérica e do analista (HORNE, 2007, p. 61).

Desse modo, o discurso é o que permite o laço social e há possibilidades de giros determinando qual discurso está operando dependendo dos lugares que cada elemento ocupa.

No caso do discurso do mestre, o agente é o senhor que se autoriza em sua própria subjetividade, já o da universidade o agente é o saber. Quanto ao discurso do analista, o agente é o objeto $a$ (discorremos com mais vagar sobre este) e por fim, no discurso da histérica o agente é o lugar do desejante. No contexto escolar, por exemplo, o interessante é que haja um giro nesses discursos de modo a não haver fixação em nenhum deles (PEREIRA, 2005) .

No decorrer de nosso trabalho, mobilizaremos o nomeado discurso do capitalismo que foi entendido como uma mutação do discurso do mestre (HORNE, 2007), sendo uma importante condição em nossa atualidade relacionada a uma ausência ou precariedade dos laços.

Efetuadas as considerações acima, remeteremos-nos a uma citação do Orlandi (2015) para nos ajudar a mobilizar as contribuições da AD para o presente trabalho: 
A análise do discurso, como o próprio nome indica, não trata da língua, não trata da gramática, embora todas essas coisas lhe interessem. Ela trata do discurso. E a palavra discurso, etimologicamente, tem em si a idéia de curso, de percurso de correr por, de movimento. O discurso é assim palavra em movimento, prática de linguagem: com o estudo do discurso observa-se o homem falando (ORLANDI, 2015, p. 15).

Então, não se trata de analisar contéudo e sim o funcionamento dos discursos e as posições ocupadas. Soler (2016) ressaltou que cada discurso delimita justamente aquilo que é recomendado e o que é reprovado por seus assujeitados conforme o lugar que eles se encontram, esse assujeitamento destacado por ela é ao inconsciente. Quanto à AD pecheuxtiana, o assujeitamento é à ideologia (ORLANDI, 2015).

Sobre o inconsciente, discorremos com mais vagar no próximo ítem deste capítulo. Para explicar a ideologia, iniciaremos com a contribuição de Chauí (2015) que, a partir do pensamento marxista, afirmou ser a ideologia um fenômeno decorrente do modo de produção econômico e correponde a uma:

...rede de imagens ou um conjunto de representações sobre os seres humanos e suas relações, sobre as coisas, sobre o bem e o mal, o justo e o injusto, os bons e os maus costumes, etc (CHAUÍ, 2015, p. 483)

Essa rede está relacionada a aparência dos fenômenos nos quais "o que é causa parece ser efeito" (CHAUÍ, 2015, p. 482), há um apagamento das origens no qual o que é social é compreendido como natural, dado.

Para além da ideologia postulada no pensamento marxista, a $\mathrm{AD}$ incluiu questões discursivas ao fenômeno de modo a questionar a ideologia enquanto um conjunto de representações, segundo Orlandi (2015):

Enquanto prática significante, a ideologia aparece como efeito de uma relação necessária do sujeito com a língua e com a história para que haja sentido. E como não há uma relação termo-a-termo entre linguagem/mundo/pensamento essa relação torna-se possível porque a ideologia intervém com seu modo de funcionamento imaginário. São assim as imagens que permitem que as palavras "colem" com as coisas. (ORLANDI, 2015, p. 48)

Portanto, a AD ressignifica a ideologia marxista de modo a introduzir as questões da linguagem. Pêcheux (1988 apud LAUREANO, 2008) destacou que a ideologia opera por meio de fenômenos nomeados como esquecimentos um e dois. O esquecimento número um é aquele em que tem o efeito de o sujeito ter a ilusão de que o seu dizer se 
origina nele mesmo, não foi a partir de outro discursos. $\mathrm{O}$ esquecimento número dois, refere-se a ilusão de que o que é enunciado é o mesmo que a enunciação, ou seja, que o quando falamos não estamos dizendo a mais do que controlamos ou, até mesmo, o contrário do que acreditamos dizer.

Sobre a relação da AD e da psicanálise, Orlandi (2015) nos ensinou que a primeira possui a psicanálise como uma de suas filiações teóricas, juntamente com o marxismo e a linguística. A contribuição da psicanálise diz respeito ao deslocamento da noção de homem, trata-se de sujeito assujeitado, ou seja, que não tem total controle sobre seu dizer.

Assim sendo, identificamos a necessidade de entendermos a noção de sujeito. Trabalhamos com o pressuposto de que não se trata de um sujeito empírico e classificável. Laureano (2008), valendo-se do pensamento pecheuxtiano, ressaltou que o sujeito é uma posição e corresponde a um efeito que se constitui a partir da interpelação ideológica. Já para a psicanálise, trata-se de um sujeito do inconsciente, de um sujeito dividido.

Para discorrer sobre sujeito lacaniano, referenciamos Elia (2010) que escreveu um livro sobre o tema no qual destacou que sujeito não é um conceito, mas algo que supomos existir visto que se impõe a nós na experiência:

Somos forçados a supor o sujeito quando reconhecemos o significante (e não nós) quem supõe o sujeito. $\mathrm{O}$ sujeito é pois, uma suposição do significante, que se impõe a nós (ELIA, 2010, p. 70).

Retomando os pressupostos do assujeitamento, podemos ressaltar que se trata de resistir a esse assujeitamento, então para existir o sujeito é necessário existir o assujeitamento para assim se constituir o sujeito, em um ato de resposta.

Quanto ao sujeito ideologicamente assujeitado como é proposto por Pêcheux (1988 apud LAUREANO, 2008), entendemos como posição tomada frente aos discursos. Portanto, também é um efeito, uma resposta.

Laureano (2008) defendeu que há uma complementaridade entre o sujeito da AD pecheuxtiana e da psicanálise que não corresponde a sobrepor esse dois conceitos de sujeito em um só, trata-se de uma complementaridade. Assolini (2003) também se valeu do pensamento pecheuxtiano para ressaltar que o inconsciente e ideologia estão materialmente interligados, a materialização se dá por meio do discurso.

Vale destacar que entendemos a complementaridade acima apresentada não em um sentido de totalidade, visto que a própria linguagem nos interdita o tudo dizer. $\mathrm{O}$ furo do entendimento sobre sujeito sempre estará presente, mas as contribuições da psicanálise e 
AD pecheuxtiana podem nos ajudar a pensar o sujeito em seus aspectos ideológicos e do inconsciente.

Portanto, o discurso aqui trabalhado é tal que enunciado e enunciação nunca formarão uma unidade, haverá sempre uma divisão no dizer e cabe a nós psicanalistas ou analistas do discurso buscar indícios da possível verdade do sujeito. Finalizamos este tópico ressaltando que "O discurso freudiano estaria sempre marcado pelo seu avesso, no caso, o inconsciente.” (PEREIRA, 2005, p. 104).

Prosseguimos então com as noções fundamentais da psicanálise, entre elas o inconsciente.

\subsection{Preceitos básicos do pensamento psicanalítico}

Iniciaremos este tópico com a noção mais fundamental do pensamento psicanalitico do teórico Sigmund Freud (1856-1939), a saber: o inconsciente.

Freud (1856-1939) era um médico e pesquisador que se interessou em estudar mulheres com graves patologias como cegueiras, paralisias e outras, que não eram explicadas pelas suas condições orgânicas. Essas condições eram nomeadas como histerias (FREUD, 2006a).

Por meio do ensino de seu professor Jean-Martin Charcot (1825-1893) utilizou a técnica da hipnose para tentativa de entendimento e cura do fenômeno (Freud, 2006a), mas a abandonou. Elia (2010) ressaltou que essa técnica foi abandonada porque era efeito de uma sugestão e não interferia de fato naquilo que mantinha os sintomas, o próprio sujeito do inconsciente.

Então, do que se trata o inconsciente? Elia (2010) ressaltou que é algo que se impõe e é impossível uma versão intelectualista ou erudita dele, visto que não é deste tipo de saber que se trata. Também não é um senso comum, visto que o inconsciente é particular. Sobre o dito senso comum, o próprio Lacan (2011) ressaltou "Existe o senso, mas não existe comum" (LACAN, 2011, p. 85), enfatizando então algo de uma particularidade.

Freud (2013) em seus estudos sobre as histéricas compreendeu que os sintomas delas eram formações substitutivas aos conteúdos reprimidos e traumáticos, e estes não eram acessíveis conscientemente. A partir desta experiência clínica, Freud (2013) postulou o inconsciente que emergia disfarçado e por meio da fala em associação livre, pelos sonhos, por chistes e atos falhos. 
Lacan (2008a) retomou o pensamento freudiano para pensar o inconsciente, mas foi além. Em suas palavras:

Tropeço, desfalecimento, rachadura. Numa frase pronunciada, escrita, alguma coisa se estatela. Freud fica siderado por esses fenômenos, e é neles que vai procurar o inconsciente. Ali, alguma outra coisa quer se realizar - algo que aparece como intencional, certamente, mas de uma estranha temporalidade. O que se produz nessa hiância, no sentido pleno do termo produzir-se, se apresenta como um achado. É assim, de começo, que a exploração freudiana encontra o que se passa no inconsciente. (LACAN, 2008a, p. 32)

O trecho acima foi retirado do ínicio do Seminário 11 de Lacan (2008a) no qual discorreu sobre os quatro conceitos fundamentais da psicanálise, entre eles, o inconsciente, que podemos apenas efetuar uma aproximação e não uma efetiva conceituação racional. Trata-se de uma hiância, uma descontinuidade no discurso na qual percebemos sermos divididos, não termos total controle do nosso dizer e do nosso agir.

Lacan (2008a) também foi além do pensamento freudiano ao afirmar que o “inconsciente é estruturado como uma linguagem” (LACAN, 2008a, p. 27), isso não quer dizer que é uma linguagem. Quer dizer que tem a mesma estrutura dela, de modo que a linguística foi um instrumento que nos ofereceu possibilidades de aproximarmos do inconsciente como "algo de qualificável, de acessível, de objetivável" (LACAN, 2008a, p.28).

Soler (2016) ensinou que Lacan (1901-1981) foi além do pensamento freudiano por ter pensado a psicanálise em termos de linguagem como um operador de efeitos e não somente um instrumento de comunicação. Esse efeito foi nomeado como falta, falta a ser, simbolizado pelo falo como efeito inerente ao simbólico.

Para situarmos a noção de falo, remetemo-nos a Elia (2010), este destacou, a partir do pensamento lacaniano, ser um significante o que:

“...permite ao sujeito acesso a um ponto para o qual não há signficante algum, o ponto em que o sexual como tal não se faz representar no inconsciente" (ELIA, 2010, p. 65)

Elia (2010) destacou que tanto no pensamento freudiano quanto lacaniano foi postulado que não há inscrição das diferenças sexuais no inconsciente. O que podemos representar de modo inconsciente é o falo como significante. 
Portanto, Lacan (1901-1981) partiu do inconsciente freudiano e inseriu a linguística para seu estudo, rompendo como uma visão de que o inconsciente fosse algo obscuro.

A partir da descoberta do inconsciente, a psicanálise foi sendo estudada e ampliada, Dunker, Paulon e Milán-Ramos (2017) ao comentarem a obra freudiana, destacaram que a psicanálise é uma teoria, método de tratamento e de investigação. Em sua intenção inicial corresponde a uma experiência de fala em contexto de tratamento, mas também corresponde a uma prática, método, ética e também a um discurso.

Lacan (2003) mencionou uma psicanálise em extensão, que corresponde a presentificação da psicanálise no mundo para além do contexto clínico, ou seja, um modo de entendimento para diversos campos, entre eles a educação.

Desse modo, mesmo um sujeito não estando na experiência de análise, o inconsciente estará se manifestando sendo possível sua escuta em situações não clínicas, ou seja, em extensão ao enquadre clínico com fins de terapêuticos.

Outro aspecto imprescindível do pensamento psicanalítico diz respeito a sexualidade como determinante das constituições dos sujeitos. Freud (2013), ao estudar os sintomas de pacientes neuróticos, notou que os desejos patogênicos eram da natureza de componentes pulsionais eróticos e assim identificou a etiologia sexual dos sintomas.

Sobre a etiologia sexual dos sintomas, destacamos a seguinte citação de Freud (2013):

\footnotetext{
Vemos que as pessoas adoecem quando, devido a obstáculos externos ou falta de adaptação interna, não acham satisfação para suas necessidades eróticas na realidade. Vemos que então se refugiam na doença, a fim de, com o auxílio desta, encontrar uma satisfação substitutiva para o que lhes é negado. Percebemos que os sintomas patológicos constituem uma parte da atividade sexual do indivíduo ou até mesmo toda a sua vida sexual, e enxergamos no distanciamento da realidade a principal tendência, mas também o principal dano causado pela doença (FREUD, 2013, p. 209).
}

A sexualidade é universal para o ser humano e já está presente desde a infância, vale destacar que ela é algo mais amplo do que a genitalidade. Para entendermos essa ampliação, faz-se necessário mencionarmos o pensamento freudiano de que a sexualidade está relacionada ao princípio do prazer, este corresponde a uma tendência do aparelho psíquico em descarregar tensão. A tensão é vivida como desprazer e a descarga de tensão como prazer (ALBERTI, 2004).

Na obra Três ensaios sobre a teoria da Sexualidade, Freud (2017a) discorre que a sexualidade já é manifestada desde a infância por meio do que chamou de organizações 
pré-genitais, a primeira é a oral ou canibal e corresponde a uma atividade sexual não separada da ingestão de alimentos. A meta dessa organização é a incorporação que "depois terá, como identificação, um papel psíquico relevante" (FREUD, 2017a, p. 108). Mais adiante, discorrermos sobre a identificação com mais vagar.

Outra organização é sádico-anal, em que a fonte das excitações vêm do anûs e a atividade relacionada ao apoderamento por meio da musculatura do corpo (FREUD, 2017a) .

Assim, a sexualidade tem a ver com as fontes, metas e objetos. Somente no decorrer do dito desenvolvimento psicossexual que essas metas podem ou não coencidirem com a função reprodutiva.

Então, o componente erótico da sexualidade diz respeito à satisfação e às zonas erógenas que vão muito além da genitalidade. Como mencionamos, nas crianças a sexualidade já é manifestada, exemplos: sucção, manipulação de excrementos, atividade masturbatória, olhar e ser olhada, enfim, há uma vasta possibilidade de satisfação e é disso que se trata (FREUD, 2013).

Vale destacar o comentário de Elia (2010) que afirmou que Freud (1976 apud ELIA, 2010) no texto A organização genital infantil: uma interpolação à teoria da sexualidade ressignificou os Três ensaios ensaios sobre a teoria da Sexualidade pensando a questão sexual a partir da lógica fálica, para além da sexualidade dita polimorfa (oral e anal).

Após Freud (1856-1939) tivemos muitos estudiosos da psicanálise, entre eles Lacan (1901-1981). Laureano (2008) comentou que a teoria lacaniana foi uma elaborada a partir do pensamento freudiano, utilizou-se também do pensamento do linguista Ferdinand de Saussure (1857-1913). No pensamento lacaniano a relação entre significante e significado, como vimos no primeiro item deste capítulo, não é fixa, de modo que há uma primazia do significante em relação ao significado. Ou seja, um significante pode circular em diferentes significados, não é colado ao significado.

Além disso, destacam-se dois modos de funcionamento similares às figuras de linguagem em relação com o significante: a metáfora que surge entre dois significantes quando um substitui o outro, e a metonímia que é meio pelo qual se liga palavras a partir de um significante de modo a ocultá-lo (LAUREANO, 2008).

Complementamos a idéia com Soler (2016) ao afirmar que o signo se define por ser substituível, mas considerando que esse não é o caso dos significantes que representam o sujeito, visto que os atributos que o marcam e os semblantes que o orientam não são 
substituíveis. Também fez referência ao significante primordial que foi nomeado como traço unário. Trata-se de um significante do trauma inicial que está fora da cadeia e sem sentido, assim, o sintoma seria a metáfora construída sobre esse o significante enigmático do trauma sexual.

Efetuada as aproximações com o que entendemos ser o inconsciente e a sexualidade, discorremos sobre a chamada transferência, este conceito se faz imprescindível ao se pensar uma pesquisa em psicanálise.

Soler (2016) destacou que a transferência é um laço em que o paciente endereça sua fala ao analista quando o coloca em um lugar de sujeito suposto saber. Não corresponde a uma relação dual, intersubjetiva, ela atua como um terceiro na relação que vai mediar e permitir o trabalho de análise, correspondendo então a um laço do desejo do analisante (desejo que o fez chegar à análise) com o desejo do analista (desejo de ocupar esse lugar).

O que principalmente nos interessa no presente trabalho é que não é apenas em um contexto de análise que ocorre a transferência, mas ela está presente nas diversas relações. Esta transferência presente nas relações não analíticas foi nomeada como selvagem (LACAN, 2005a).

Então, considerando que a transferência pode estar presente nas diversas relações para além da analítica, Voltolini (2011) afirmou que ela é um processo que faz com que dada pessoa funcione para nós de acordo com uma suposição que fazemos dela, mais do que por seus atos e discursos.

A psicanálise pressupõe noções básicas para que possamos trabalhar a partir dela, neste tópico apresentamos algumas de modo a nos aproximarmos em relação à nossa questão de pesquisa. Prosseguiremos então com a mobilização de outros conceitos que entendemos estar relacionados.

\subsection{O lugar do Outro}

Discorremos até então sobre o retorno de Lacan (1901-1981) ao pensamento freudiano indo além dele, pensando o inconsciente estruturado como uma linguagem. Tendo isso em vista, destacaremos a noção de Outro.

O Outro é "tudo que não é eu, mas interpela" (BAIRRÃO, 2001, p. 15), é o que se apresenta como um interlocutor fundamental para que surja um sujeito. Alberti (2004) ressaltou que é o Outro é apresentado em letra maiúscula porque não se trata de um outro 
qualquer, mas sim deste que o ampara no desamparo fundamental e o mergulha no mundo simbólico. Para se constituir, o sujeito precisa estar alienado ao Outro, porém, esse Outro também deve ser barrado pela incompletude.

Para melhor entendermos, faz-se necessário mobilizar outras noções que estão entrelaçadas ao Outro além de retomar o sujeito como um ato de resposta, assim como nos ensinou Elia (2010).

Dor (1989), ao comentar a obra freudiana, esclareceu que o primeiro registro de satisfação da criança desenrola-se num registro essencialmente orgânico. Usaremos como exemplo o objeto leite que é oferecido à criança sem que ela busque, objeto aqui é da ordem da pura necessidade porque não tem uma mediação. Essa primeira experiência é perdida e deixa um traço mnésico ao nível do aparelho psíquico, este constitui a representação do processo pulsional para a criança.

Vale ressaltar sobre pulsão a contribuição de Elia (2010) quando nos ensina que ela é "experiência do instinto fragmentado e remodelado pelo significante (ELIA, 2010, p.47). Então, o ser humano, sendo inserido no campo da linguagem, não estabelece uma experiência direta instintiva como outros animais e sim pulsional, ou seja, já sob efeito da linguagem.

Retomando, o traço mnésico será reinvestido e orientará as buscas em direção ao objeto de satisfação. Então, o desejo freudiano é o desencadeamento de um impulso que investirá novamente a imagem mnésica de modo a reconstituir a situação da primeira satisfação. O desejo mobiliza o sujeito em direção ao objeto pulsional, mas não tem objeto na realidade (DOR 1989).

Dor (1989) destacou que o desejo lacaniano diz respeito a um aprofundamento da noção freudiana. Retomando o exemplo da primeira satisfação alimentar, os estados de tensão do corpo são nomeados por aquele que cuida dela e que interpreta as respostas como demanda. O outro que está cuidando da criança dá sentidos para as respostas que ela apresenta em relação às tensões, assim a criança é assujeitada, mergulhada, ao universo simbólico desse que a tutela.

Esse lugar de inscrição no universo simbólico que o outro pode encarnar é o lugar do primeiro Outro na qual se estabelece uma relação de alienação.

A oferta do objeto suposto para a satisfação da criança traz um repouso orgânico que a mãe (ou quem faz suas vezes) responde com seus gestos e palavras, esse a-mais é vivido como um gozo para a criança. 
Vale ressaltar que podemos entender o gozo como:

“...essa tensão corporal interna que nos dá a impressão de estarmos vivos, mas não conseguimos significá-lo exatamente com um significante que o represente ou o meça" (NASIO, 2011, p. 61)

Vale lembrar que Elia (2010) nos ensinou que podemos entender que o sujeito é uma resposta à operação de alienação ao Outro.

Essa busca nos faz ressaltar o que é comumente escutado em meios psicanalíticos que o objeto $a$ é causa do desejo, é o lugar que o analista maneja para que venha a ocupar para o analisando, para isso é necessário uma hiância, um intervalo.

Sendo assim, o desejo é uma tentativa de reencontro com a satisfação originária que está perdida, que não foi mediada por uma demanda. É uma tentativa de reencontro com o primeira experiência de gozo. Da posição de assujeitamento a criança, o sujeito por vir, necessitará demandar e ser conduzida a significar o que deseja. O demandar introduz uma inadequação entre o que é desejado é o que se faz ouvir, marcando o impossível reencontro do gozo primeiro com o Outro (DOR, 1989).

Laplanche e Pontalis (2001) também contribuíram para a explicação do conceito de desejo em relação aos conceitos de necessidade e demanda. É afirmado que a necessidade se relaciona com um objeto real, indizível, já o desejo se relaciona com a fantasia, ou seja, com uma elaboração psíquica que faz mediação com o objeto real. Demandar se refere a nomear um pedido, e o desejo é algo que o sujeito não consegue formular por meio de um pedido verbal e consciente. Desse modo, o desejo corresponde a própria falta que nos impulsiona a continuar vivendo.

A partir do exposto, compreendemos a importância do outro que encarna o Outro para o ser humano, como modo de orientar a instauração do desejo e do próprio sujeito.

Para proseguimento de nosso embasamento téorico, faz-se necessário também discorrer sobre os três registros postulados na teoria lacaniana, a saber: imaginário, simbólico e o real, que estão articulados aos conceitos de Outro e de identificação. 
Lacan (2005b) nos ensinou que o imaginário tem a ver com a imagem e com as relações duais. Em seu trabalho $O$ estádio do espelho como formador da função do eu e tendo como referência o pensamento walloniano, Lacan (1998a) ensinou que o referido estádio corresponde a uma instauração do eu, à transformação produzida na criança quando ela assume uma imagem.

Trata-se de um acontecimento em que a criança reconhece a si no espelho e efetua uma síntese por meio da imagem de modo a superar a experiência de corpo esfacelado. Essa imagem situa a instância do eu antes de uma determinação social, mas desde que um Outro o confirme essa imagem (LACAN, 1998a).

Ao comentar o pensamento lacaniano, Dunker, Paulo e Milán-Ramos (2017) destacaram que o plano imaginário é representado pela significação de modo a poder antecipar e se reconhecer na mensagem. Então, a relação dual é o registro imaginário de nossa existência, instaurada na antecipação por meio do reconhecimento de si em uma imagem.

Já o registro simbólico corresponde a uma relação mediada, não mais dual (LACAN, 2005b). O simbólico está operando quando o Outro constitui-se como barrado, mas também nos remetemos ao complexo de Édipo para compreendermos a entrada na lei simbólica, do desejo: Sobre isso, vale citarmos Freud (2013):

É inevitável, e inteiramente normal, que a criança tome os pais como objetos de sua primeira escolha amorosa. Mas sua libido não deve permanecer fixada nesses primeiros objetos, deve apenas tomá-los depois como modelos e passar deles para outras pessoas, na época da escolha definitiva de objeto. $\mathrm{O}$ desligamento da criança em relação aos pais tornase, então, uma tarefa inelutável, para que a aptidão social do jovem indivíduo não venha a ser comprometida (FREUD, 2013, p. 208)

O psicanalista argentino Násio (2007) destacou que, em seu contexto familiar adicionamos aqui também uma instituição que faça as vezes de amparo - a criança em certo momento de sua vida, vivencia o desejo sexual próprio de um adulto e o direciona às referências familiares. Essa elaboração corresponde ao conflito edipiano, conflito entre o prazer erótico e o medo. A criança deverá aprender a limitar seus impulsos e ajustá-los ao limite de seu corpo. Quando ela recalca o desejo incestuoso, descobre o pudor, o senso moral e inicia o estabelecimento de sua identidade. 
Após essa vivência, que poderá ser revivida em diversos momentos da vida, é elaborada a interdição do incesto que representa a não possibilidade de total satisfação do desejo. Assim, possibilita que o sujeito seja marcado por uma lei simbólica que o permite abdicar de seus desejos para internalizar as regras de um grupo. (DOLTO, 2010; NÁSIO, 2007; ROUDINESCO, 2003). Esse aspecto de mediação de uma referência de lei, de um interdito, corresponde ao aspecto simbólico humano.

Vale ressaltar que a proibição incestuosa entre ascendente e descendente é universal, e dá origem e continuidade à sociedade. É a passagem da natureza para a civilização. (LÉVI-STRAUSS, 1976).

Násio (2007) ressaltou que a elaboração do complexo de Édipo oferecerá ao sujeito traços e aptidões para gerir conflitos, e será um protótipo utilizado para a elaboração de conflitos no decorrer de sua vida.

Então, o aspecto simbólico diz respeito a uma mediação. Há o simbólico instaurado com o traço inaugural, no início da vida, bem como o aspecto simbólico pensando a partir do conflito edipiano.

Quanto ao registro do real, vale destacar que é o que escapa da nomeação "é ou a totalidade ou o instante esvanecido" (LACAN, 2005b, p. 21). Para Soler (2016), o real é um impossível de se formular faz objeção a ordem do discurso e portanto ao laço social, ressaltou que há um real próprio a cada discurso (SOLER, 2016).

Portanto, o real é aquilo com o qual nos deparamos e que nos escapa da nomeação.

Os três registros estão implicados nos processos de identificações. Laplache e Pontalis (2004), ao se valerem do pensamento freudiano, ensinaram-nos que a identificação é, de um modo geral, uma operação em que o sujeito se constitui ao assimilar aspecto, propriedade ou atributo do outro os transformando.

Nasio (1989) também discorreu sobre a referida noção no pensamento freudiano e lacaniano, afirmando que:

Enquanto Freud propõe o nome de identificação para qualificar a relação intrincação entre duas instâncias inconscientes - o eu e o objeto -, Lacan, em contrapartida, enfrenta um outro problema mais delicado e difícil. $\mathrm{O}$ conceito lacaniano de identificação responde a um desafio mais extremo do que o desafio freudiano, já que não se trata mais de dar conta da relação entre dois termos relativamente bem constituídos - um eu determinado identificando-se com um objeto igualmente definido -, mas 
de dar nome a uma relação em que um dos termos cria o outro. Para Lacan, a identificação é o nome que serve para designar o nascimento de um nova instância psíquica, a produção de um novo sujeito. (NÁSIO, 1989, p. 101).

Quanto a constituição de um sujeito, Násio (1989) destacou que ocorre na identificação primordial, simbólica, em que a criança se identifica com o traço unário, este é definido como uma marca do primeiro significante, traço que unifica o conjunto dos significantes, nos primeiros momentos da vida quando a criança é inserida na linguagem. Então, corresponde a uma marca simbólica anterior ao do complexo de Édipo.

Sobre as identificações simbólicas a partir do complexo de Édipo. Laplache e Pontalis (2004), destacaram que corresponde a uma vivência em que os investimentos libidinais ambivalentes às figuras parentais são substituídos por identificações.

Já a identificação imaginária diz respeito ao nascimento do eu na vivência do estádio do espelho, trata-se de um momento em que a criança é captada pela visão global de sua imagem refletida no espelho. $\mathrm{O}$ eu nasce como marca do contorno da imagem unitária da criança. No decorrer da vida, o eu vai se identificando com as imagens em que se reconhece e que evocam "apaixonadamente a figura humana do outro, seu semelhante" (NÁSIO, 1989, p. 117).

Vale também ressaltar que Roudinesco e Plon (1998) destacaram o pensamento lacaniano, em que foram pontuados três tempos do referido complexo:

...sob a forma de uma identificação com o que se presume ser o desejo da mãe, depois, sob a forma descoberta da lei do pai e, por fim, sob a da simbolização dessa lei, que tem como efeito atribuir ao desejo da mãe seu verdadeiro lugar e permitir as identificações posteriores, constitutivas do sujeito (ROUDINESCO; PLON, 1998, p. 365).

Portanto, destacamos que os sujeitos são instaurados a partir do Outro, encarnado nas figuras parentais ou substitutos, de modo que o Outro possui função primordial no constituição e na vida dos sujeitos (NÁSIO, 1989).

Efetuadas as mobilizações sobre o Outro e suas implicações, prosseguiremos em nosso capítulo apresentando outras noções a serem mobilizadas. 


\subsection{Psicanálise e os laços}

Laço é um significante presente no título de nossa pesquisa e vamos mobilizá-lo a partir do pensamento psicanalítico. Soler (2016) destacou que no pensamento freudiano não foi utilizado o termo laço, mas foi questionado sobre o que funda a civilização. Desse modo, partiremos da noção de civilização freudiana para discorrer sobre os laços.

Remetemo-nos a uma importante obra de Freud (1856-1939) O mal-estar na civilização que recebeu uma prêmiação concedida às obras científicas: o prêmio Goethe (ELIA, 2010). Sendo assim, iniciaremos a mobilização da noção de civilização a partir do que Freud (2010a) pensou:

... a palavra "civilização" designa a inteira soma das realizações e instituições que afastam a nossa vida daquela de nossos antepassados animais, e que servem para dois fins: a proteção do homem contra a natureza e a regulamentação dos vínculos dos homens entre si (FREUD, 2010a, p.49).

O trecho define que a civilização corresponde a passagem de um total domínio da natureza para certo controle da mesma, bem como a regulamentação da vida em grupo que somente foi possível as custas de reprimirmos nossos impulsos e com efeitos para os sujeitos, de modo que haverá sempre um mal-estar inerente a vida em civilização (FREUD, 2010a).

Esses efeitos podem ser dores, decepções e tarefas insolúveis, mas utilizamos paliativos para suportar o mal-estar. Amar e ser amado é uma das principais maneiras de lidar com o sofrer, mas na verdade "cada um tem que descobrir a sua maneira particular de ser feliz" (FREUD, 2010a, p. 41).

Também podemos utilizar de gratificações substitutivas para lidarmos com o mal-estar, trata-se do que foi nomeado como sublimação: quando os impulsos não condizentes com a vida em civilização são deslocados em sua finalidade, ou seja, investidos em ações que contribuem para a humanidade, como ocorre na criação de uma obra de arte ou de alguma importante invenção (FREUD, 2013).

Trata-se de deslocamento das metas dos impulsos ofertando ganho de prazer por meio de fontes de trabalho psíquico e intelectual. A sublimação requer talentos e disposições que 
podem não estar presentes em todos os seres humanos (FREUD, 2010a), porém, pode ser um refúgio para alguns.

Ainda em Mal-estar na civilização, Freud (2010a) demonstra que o que entendemos por civilizadas são condutas ditas inúteis quanto as necessidades biológicas visando a sobrevivência da espécie, por exemplo a beleza. Apreciar a beleza é um modo civilizado de obtenção de prazer. Além disso, no processo civilizatório, questões como a limpeza e ordem estão presentes, e a estima e cultivo de atividades psíquicas ditas mais elevadas. E, o mais característico, diz respeito ao modo como são reguladas as relações humanas, vale citar:

A vida humana em comum se torna possível apenas quando há uma maioria que é mais forte que qualquer indivíduo e se conserva diante de qualquer indivíduo. Então o poder dessa comunidade se estabelece como "Direito, em oposição ao poder do indivíduo, condenado como "força bruta". Tal substituição do poder do indivíduo pela comunidade é o passo cultural decisivo. Sua essência está em que os membros da comunidade se limitam quanto as possibilidades de gratificação, ao passo que o indivíduo não conhecia tal limite (FREUD, 2010a, p. 56).

Portanto, na visão freudiana, a vida em civilização requer ir além das necessidades biológicas, o humano transcendeu a essas questões graças as possibilidades advindas de seu aparelho psíquico que é constituído na relação com outro ser humano.

A origem freudiana da civilização foi pensanda enquanto uma narrativa: o mito da horda primeva. Trata-se de uma fabulação em que havia um pai primitivo de gozo absoluto, que tinha acesso a todas as mulheres e que todo homem da horda aspirava. Os filhos assassinaram esse pai, mas o acesso a todas as mulheres continuou proibido, mas não pela força e sim pelo pacto firmado pelo qual os irmãos se submeteram. Essa lei metaforizada pela morte do pai, diz respeito ao simbólico freudiano (SOLER, 2016).

Assim, o mito da horda primeva indica que é necessário ter uma perda primeira para que a regulação de um laço social seja possível, pode-se dizer que esse é o mito da gênese histórica do desejo (SOLER, 2016).

Retomando o significante laço, Soler (2016) destacou que aquilo que o pensamento freudiano postulou como civilização, o lacaniano se referiu como discurso. O que faz laço é o discurso. Atualmente vivenciamos uma sociedade incitadora e de precariedade de laços, desse modo, Soler (2016) nos convida a pensar sobre o que está no princípio do desenlace e ressaltou uma tese lacaniana de que a causa capitalista não enlaça os indivíduos e sim deixa cada um reduzido a seu corpo, de modo que os grupos acabam sendo agregados de multidões. 
Ao mencionar a causa capitalista, ressaltamos o que foi pensado por Lacan (2011) como o discurso do capitalismo. Vale lembrar de que discorremos sobre os quatro discursos lacanianos no primeiro ítem do presente capítulo.

Para Horne (2007), valendo-se do pensamento lacaniano, o discurso do capitalismo é uma mutação do discurso do mestre. É uma mutação porque não corresponde a um giro articulado dos elementos, no discurso do capitalismo o sujeito toma o lugar de senhor sendo o efeito um "pseudodiscurso" (HORNE, 2007, p. 62) que não enlaça.

Nas palavras do próprio Lacan (2011):

O que distingue o discurso capitalista é isto: a Verwerfung, a rejeição para fora de todos os campos do simbólico, com as consequências de que já falei - rejeição de que? - Da castração. (LACAN, 2011, p. 88).

$\mathrm{Na}$ experiência clínica, podemos notar os efeitos disso nos sintomas relacionados a um automatismo, podendo ser expressado pelas autolesões no corpo, abuso de drogas e busca de uma complementariedade nos chamados gadgets (objetos eletrônicos, principalmente celulares).

Para Horne (2007), no discurso do capitalismo:

"Poderíamos dizer que o sujeito, a rigor, não é o sujeito dividido, no sentido de dividido entre os significantes de um discurso. Trata-se, muito mais, de um sujeito solidificado no gozo." (HORNE, 2007, p. 62).

Assim, na atualidade vivemos a predominância de um "pseudodiscurso" (HORNE, 2007, p. 62) que não faz laço, não envolve o Outro, rejeita a castração. O que nos faz viver em agregados.

O agregado está relacionado ao processo de identificação, Soler (2016) diferenciou a identificação de alienação que é tomada emprestada do Outro e a identificação ao sintoma. Entende-se sintoma como um acontecimento do corpo e metáfora, é uma função de satisfação, seja assumida ou recusada. Trata-se de uma fixação que faz destino e que 
determina o gozo do sujeito. O processo de análise pode mover essas fixações dependendo do elemento fixador e da relação com o Outro.

Ao se pensar sociedade e laço social, Soler (2016) destacou que não é o ideal que cada um se identifique com um gozo singular, porém, criticou que os laços também não podem ser os de exército, em que o membros se identificam a partir da identificação com um líder inquestionável. Desse modo a autora se questionou? "o que é necessário para fazer uma sociedade solidária, laço social, portanto, da tropa dos esparsos consumidores?" (SOLER, 2016, p. 48).

Ao discorrer sobre isso, a autora referiu-se ao pensamento lacaniano para destacar os chamados cartéis como grupos para estudo da Escola de Psicanálise que visa uma identificação ao grupo. Não se trata de uma estrutura competitiva, os quatro integrantes de um cartel estarão em pares e reunidos por uma tarefa em comum. A identificação no cartel se dá com o lugar do objeto $a$, ou seja, "ao objeto que falta ao atar do nó" (SOLER, 2016, p. 50). Identifica-se um a cada um na medida em que se trabalhe a partir de um não saber, trata-se de uma identificação por participação.

Por último, destacamos que a queixa sobre os dos desenlaces presente nos meios de comunicação, no um a um, ou seja, nas particularidades de cada sujeito; e em produções culturais que tem as palavras mestras solidão e precariedade; isso é um efeito histórico de capitalismo globalizante, porém associal. O Outro do discurso mudou, faltam semblantes que consigam fazer convergir e orientar (SOLER, 2016).

Após aproximarmos da noção de laço, ou não laços no caso da atualidade, partiremos para as questões envolvendo a psicanálise e educação tendo em vista nossos objetivos de pesquisa.

\subsection{A psicanálise e contribuições para o educar}

Inicialmente, ressaltamos que, tratar das questões da educação a partir dos referenciais psicanáliticos, corresponde a uma psicanálise em extensão, assim como propôs Lacan (2003), ou seja, extensão para além de objetivos terapêuticos. 
Tendo isso em vista, Voltolini (2011) ressaltou que é possível contribuição da psicanálise ao tema da educação se houver um deslocamento do termo educação para educar. Esse deslocamento de um substantivo para um verbo permite uma abertura enquanto uma posição discursiva, visto que permite a articulação de outros saberes no contexto das ciências da educação.

Sendo assim, destacamos uma citação de Freud (2006b) retirada de seu trabalho Prefácio a Juventude Desorientada, de Aichhorn, no qual se remeteu ao pensamento kantiano para afirmar:

Minha cota pessoal nessa aplicação da psicanálise foi muito leve. Em primeiro estágio, aceitei o bon mot que estabelece existirem três profissões impossíveis - educar, curar, e governar - e eu já estava inteiramente ocupado com a segunda delas. Isto, contudo, não significa que desprezo o alto valor social do trabalho realizado por aqueles de meus amigos que se empenham na educação (FREUD, 2006b, p. 307).

Nessa citação identificamos que Freud (2006b) afirmou que o educar é impossível, mas não impraticável, visão defendida também por Voltolini (2011) ao destacar que o impossível de educar não corresponde uma impossibilidade ao plano prático de execução de uma determinada proposta educativa, mas o que não é possível é um ideal que seja aplicado a todos.

Em outro trabalho intitulado Considerações atuais sobre a guerra e a morte, Freud (2010b) discorreu sobre as elevadas normas éticas da civilização ocidental que supõem altas restrições de si por meio de renúncia das satisfações pulsionais, visando moldar o indivíduo para o ideal de comunidade civilizada. Ele argumentou que não existe uma classificação prévia entre sujeito mau ou bom, nós quem atribuímos as referidas valorizações tendo em vista as exigências da civilização.

Para melhor esclarecimento, destacamos a seguinte citação:

$\mathrm{Na}$ realidade não existe nenhuma "extirpação" do mal. A investigação psicológica - em sentido mais rigoroso, a psicanalítica - mostra, isto sim, que a essência mais profunda do homem consiste em impulsos instintuais, que são iguais em todos os indivíduos e que objetivam a satisfação de certas necessidades originais. Esses impulsos instintuais não são bons nem maus em si. Nós os classificamos dessa forma, a eles e as suas manifestações, conforme sua relação com as necessidades e exigências da sociedade humana. Há que admitir que todos os impulsos que a comunidade proíbe como sendo maus - tomemos como representativos os egoístas e os cruéis estão entre os primitivos (FREUD, 2010b, p. 163) 
A dita domesticação humana ocorreu devido aos fatores internos e externos, os primeiros dizem respeito às influências do erotismo, ou seja, pela necessidade humana de amor, assim aprendemos a estimar com a vantagem de ser amado. Já os fatores externos correspondem ao processo educativo que representa as demandas do ambiente civilizado (FREUD, 2010b).

Relembrando que pressupomos um sujeito do inconsciente, tem-se a implicação de que há uma impossibilidade de controle nas relações que deve ser considerada. Assim, não é proposto um ideal educativo, como se costuma ocorrer nos discursos pedagógicos vigentes, e sim pensarmos em condições de possibilidades para o educar de modo a considerar o inconsciente (VOLTOLINI, 2011).

Mrech (2005a) propôs questionar as normativas nas políticas públicas de educação que ditam um fazer homogêneo:

Pensar em uma Educação para o sujeito não é a mesma coisa que pensar em Educação para todos. O Todos não diz respeito ao cada um. O Todos é da ordem de um modelo moderno de Educação, que privilegia o social da categoria e não a especificidade de cada aluno (MRECH, 2005a, p. 25)

O saber inconsciente corresponde a um "saber que não se sabe" (MRECH, 2005b, p. 145). Sendo assim, Mrech (2005b) diferenciou o saber textual do referencial, o primeiro diz respeito ao saber do inconsciente estruturado como linguagem que diz da singularidade do sujeito, de suas resistências e relação com o Outro.

Já o saber referencial é o das estruturas lógicas e simbólicas, dos conhecimentos acumulados e reeleaborados no decorrer da história da humanidade (MRECH, 2005b). No processo educativo escolar se faz imprescindível considerarmos que esses dois saberes estão entrelaçados, isso implica que:

Trata-se do aluno por ele mesmo. Do aluno com o seu desejo e/ou horror de saber. Do aluno com suas categorias modais - possível, impossível, contingente e necessário. $\mathrm{O}$ encontro com o Outro - o encontro com o professor - vai ser sempre um encontro falhado. Um encontro com o real, que é sempre surpressivo e inesperado (MRECH, 2005b, p. 155).

Então, o pensamento psicanálitico aplicado à educação nos ensina a importância de questionarmos os discursos que partem do pressuposto em que há total controle nas relações de aprendizagem, a presença do sujeito do inconsciente nos mostra que esse controle não é possível. 
Para além do educar formal, escolar, Voltolini (2011), a partir do pensamento freudiano, ressaltou que o processo educativo e o processo civilizatório são tratados como sinônimos. A inclusão do sujeito no mundo da linguagem supõe uma violência primordial, visto que se trata de um assujeitamento a uma ordem específica. Porém, isso não corresponde a uma adaptação aos imperativos de uma época ou ato de crueldade, corresponde a entrada no mundo humano, a um processo de hominização.

Outro aspecto a ser mencionado, é sobre a relação professor e aluno. Voltolini (2011), valendo-se do pensamento freudiano, destacou que o professor possui em relação ao aluno uma função de modelo, ou seja, ocorre uma influência mesmo que não planejada. Assim como as crianças ocupam um lugar ideal em relação a seus familiares, os alunos também ocupam um lugar no ideal dos professores. Nas palavras do autor:

Os alunos também terão que se deparar com uma investidura de seus professores que se sustenta, em última instância, na fantasia destes." (VOLTOLINI, 2011, p. 31).

Assim, prosseguimos destacando que há algo do campo amoroso que se instala entre educando e educador, trata-se de um aspecto transferencial. Freud (1914 apud VOLTOLINI, 2011) considerou esse aspecto mais decisivo no aprendizado dos alunos do que as disciplinas que o professor ensina. Retomamos que a transferência é um processo inconsciente que faz com que dada pessoa funcione para nós de acordo com uma suposição que fazemos dela.

Pedroza (2010), também a partir do pensamento freudiano, afirmou que os professores são investidos da relação afetiva primitivamente associada a figura que exerce a função paterna. Cohen (2004) adiciona que as crianças tem buscado as funções parentais em outras instâncias para além da família, como a escola e a figura do professor. Destacou que muitas crianças, diante das demandas da educação formal, buscam limites expressando condutas transgressoras na escola, oferecendo ao professor o status de representante parental.

Assim, notamos a importância simbólica que o educador pode representar a um sujeito e esses lugares podem ou não favorecer o aprender. Em relação ao aprender, Voltolini ( 2011) ressaltou que implica um apreender indicando uma operação ativa de "ir lá e pegar algo no campo do Outro" (VOLTOLINI, 2011, p. 33). Não se trata, portanto, de um lugar passivo em que se recebe o conhecimento de um outro. 
Outra diferenciação importante é a que existe entre o transmitir e ensinar, Voltolini (2011) se remeteu a origem da palavra como sendo en-signar que quer dizer pôr em signos, de modo que exige uma intencionalidade consciente. Já transmitir indica que passamos para frente à nossa revelia, sem uma intenção consciente, considerando os aspectos transferenciais.

Todas os pontos apresentados além do próprio mal-estar inerente ao fato de vivermos em civilização, geram impasses presentes no dia a dia das escolas. Isso sem considerar as questões concretas políticas que estão postas expressas em ausência de recursos nas escolas públicas e excessiva preocupação com os lucros, como vemos em diversas escolas privadas.

Coutinho (2009) refletiu sobre os impasses na relação entre adolescência e educação a partir da experiência com grupos de reflexão com adolescentes de uma escola pública, tendo como referência a psicanálise. Enfatizou que uma das formas de compreender esses impasses é que as escolas e professores não mais ocupam o lugar de ideal cultural necessário para que constituam um lugar de autoridade. Além disso, considerou como dificultador o excesso de saber produzido pelo discurso da ciência acerca dos adolescentes, de modo que se faz necessário espaço de escuta sobre o que esses adolescentes tem a dizer.

Assim, pensar a educação e psicanálise não corresponde a praticar uma pedagogia psicanalítica e sim questionar as posições da pedagogia enquanto discursos exclusivos e homogeneizantes, e considerar os aspectos inconscientes que estão em jogo nos sujeitos e seus laços.

Portanto, entendemos ser imprescindível lidar com os impasses de modo a buscar um optimum entre o saber referencial e o saber textual. Além de buscar saídas para os impasses políticos de salas de aulas lotadas e das condições precárias advindo dos baixos investimentos em educação. 


\section{FAMÍLIA: ASPECTOS HISTÓRICOS E SOCIAIS}

\subsection{Família: da idade média à modernidade}

Iniciamos este capítulo aprensentando aspectos históricos sobre a família entendendo que estes afetam os sujeitos tendo em vista o assujeitamento ao Outro e à ideologia.

Desse modo, referenciamos o historiador Ariès (2012) para ressaltar que o sentimento de família, como vemos atualmente, emergiu a partir da modernidade quando houve uma alteração do sentimento de infância. Vale ressaltar que, segundo Roudinesco (2003), até o século XVIII, o infanticídio e abandono consistiram em meios comuns de controle da fecundidade, isso porque o filho era visto como uma "coisa" (ROUDINESCO, 2003, p. 99).

A partir das descobertas de outros tipos de controle da fecundidade como o coito interrompido, relações prolongadas sem ejaculação e até abstinência, o filho deixou de ser uma coisa para ser tornar um sujeito integral. Na sociedade burguesa pós revolução francesa, o filho será um investimento na transmissão do patrimônio, Freud (1995 apud ROUDINESCO, 2003) teorizou que essa passagem culminou que o filho permanece para os pais como prolongamento destes.

$\mathrm{Na}$ idade média, apesar da alta mortalidade infantil, as crianças ricas não eram educadas pela família de origem, mas sim levadas a uma outra família e participavam do cotidiano da vida desta. Nessa família acolhedora elas socializavam e viviam como aprendizes. As crianças pobres eram enviadas muito jovens para trabalharem como criadas e conviviam no cotidiano das tarefas (ARIÈS, 2012).

Ainda com Ariès (2012), destacamos que as famílias medievais eram compostas por linhagens que poderiam ter até duas gerações, chamadas de mesnie que compartilhavam as posses e onde circulavam os criados e protegidos. $\mathrm{O}$ enfraquecimento da linhagem e da tendência a indivisão propiciou abertura para a formação da família conjugal moderna (ARIÈS, 2012).

Foi a partir do século XV que começamos a perceber o sentimento de família moderna como temos atualmente. Ariès (2012) referenciou M. Pelot (1955 apud ARIÈS, 2012) para afirmar que nesse processo se deu um progressiva degradação da situação da mulher no lar, sendo seus direitos se tornado radicalmente nulos. A reorganização da casa e 
dos costumes deixaram espaço maior para a intimidade, reduzindo a família aos pais e filhos e excluindo os criados, clientes e amigos.

Após o século XV, a educação passou a ser fornecida cada vez mais pela escola, ou seja, a escola foi progressivamente ocupando o espaço para o educar juntamente com a constituição do sentimento de família conjugal e restrita. Ressalta-se que as meninas foram excluídas dessa educação escolar e só posteriormente inseridas, em meados do século XVII, entendendo a necessidade de uma preparação para a vida (ARIÈS, 2012).

Além disso, Roudinesco (2003) afirmou que, desde a revolução francesa, o contexto europeu vêm se constituindo por uma queda do patriarcado. Vale esclarecer que Henry Lewis Morgan (MORGAN, 1871, apud ROUDINESCO, 2003) conceituou o patriarcado como um sistema jurídico-político em que a autoridade e os direitos sobre o patrimônio e pessoas obedecem a uma regra de filiação patrilinear. Já o matriarcado, foi conceituado como sistema com filiação matrilinear que decidia sobre a autoridade sendo geralmente destinada ao tio materno. Além disso, foi destacado que nenhum dos dois sistemas existiu em estado puro na história da humanidade, o que há são prevalências de um ou outro.

Vale destacar também a contribuição de Roudinesco (2003) que distinguiu três grandes períodos na evolução da família ocidental européia. Relatou que a primeira corresponde a família dita tradicional, que tinha a principal função de assegurar a transmissão do patrimônio. Os casamentos eram arranjados pelos pais sem considerar a vida sexual e afetiva, a família era submetida a autoridade patriarcal, nas palavras dela: "verdadeira transposição da monarquia de direito divino" (ROUDINESCO, 2003, p. 19).

O segundo período de evolução das famílias (Século XVIII até meados do XX) foi caracterizado por famílias ditas modernas, fundadas pelo amor romântico que sanciona a reciprocidade de sentimentos e os desejos carnais por intermédio do casamento. Além disso, havia a valorização da divisão do trabalho dos esposos, e a responsabilidade da educação dos filhos é dividida com o Estado (ROUDINESCO, 2003).

Ressalta-se que, nesse segundo período, o pai não mais se assemelhava a um Deus soberano, como ocorria na monarquia. Desprovido de atributos divinos, o pai após a revolução francesa, se submeteu a lei da Declaração dos Direitos do Homem e do Cidadão, o casamento se torna uma contrato livre e consentido entre um homem e uma mulher (ROUDINESCO, 2003). Nas palavras da autora: 
É assim que a substituição do poder de Deus pai pelo pater familias abre caminho para uma dialética da emancipação cujas primeiras beneficiárias serão as mulheres, e depois delas as crianças (ROUDINESCO, 2003, p. 40).

Assim, esse novo lugar dado ao homem e a mulher no contexto familiar, ofertou abertura para uma gradual emancipação das mulheres e das crianças (ROUDINESCO, 2003).

O terceiro período de evolução das famílias que foi sistematizado por Roudinesco (2003) será apresentado em nosso próximo ítem, prosseguimos então.

\subsection{Um olhar contemporâneo para a família}

Iniciamos este tópico com Agamben (2009) que postulou ser a contemporaneidade uma singular relação com seu próprio tempo em que ao mesmo tempo que se adere, distancia-se. Contemporâneo é aquele que "mantém fixo o olhar sobre seu tempo, para nele perceber não as luzes, mas o escuro" (AGAMBEN, 2009, p. 62).

Assim, o sujeito contemporâneo seria aquele que consegue olhar para os furos, podendo propiciar a condição inicial de uma transformação dos pactos civilizatórios.

Destacamos Ramon e col (2016) ao enfatizaram que, no pensamento lacaniano, a subjetividade tem a ver com sua época, assim o praticante da psicanálise deve saber decifrar o movimento simbólico característico de seu momento. Desse modo, faz-se imprescindível que as reflexões sobre aspectos subjetivos considerem aspectos sociais.

Sendo assim, neste ítem do presente capítulo discorrermos sobre questões atuais efetuando a tentativa de posição do sujeito contemporâneo e pressupondo que o sujeito inserido na cultura é afetado pela mesma.

Roudinesco (2003) discorreu sobre as famílias a partir de 1960 as inserindo no que entendeu como terceiro período de evolução das famílias. Trata-se de uma organização em função da relação conjugal entre sujeitos que buscam realização sexual e não mais o amor romântico. Nessa busca pela realização os sujeitos vivenciam frequentes separações conjugais e produzem novos arranjos familiares.

O modelo familiar centrado no patriarcalismo está em queda e a sociedade necessita encontrar novas formas de transmissão da lei simbólica frente aos rearranjos familiares (ROUDINESCO, 2003). Vale citar que: 
Baseada durante séculos na soberania divina do pai, a família ocidental foi desafiada, no século XVIII, pela irrupção do feminino. Foi então que se transformou, com o advento da burguesia, em uma célula biológica que concedia lugar central à maternidade. A nova ordem familiar conseguiu represar a ameaça que esta irrupção do feminino representava à custa do questionamento do antigo poder patriarcal. A partir do declínio deste, cuja testemunha e principal teórico foi Freud ao revisitar a história de Édipo e de Hamlet, esboçou-se um processo de emancipação que permitiu às mulheres afirmar sua diferença, às crianças serem olhadas como sujeitos e aos "invertidos" se normalizarem. Esse movimento gerou uma angústia e uma desordem específicas, ligadas ao terror da abolição da diferença dos sexos, com a perspectiva de uma dissolução da família no fim do caminho" ( ROUDINESCO, 2003, p. 11)

O imaginário de uma possível irrupção do feminino com efeitos de extinção da diferença sexual e retorno da barbárie está relacionado a um certo receio sobre as conquistas das mulheres (ROUDINESCO, 2003). Esse pensamento pode nos ajudar a compreender o por quê de resistências em relação aos novos lugares conquistados pelas mulheres que afetam os novos modos de organização das famílias.

Sobre isso, faz-se imprescindível ressaltar Goldani (2002) ao afimar que as atuais mudanças nas relações conjugais são produções das alterações nas relações de gênero, no lugar ocupado pelas crianças e adolescentes na sociedade e no aumento da expectativa de vida.

Além disso, Pereira (2012) e Nasio (2007) destacaram que uma das principais influências dos atuais rearranjos familiares é a gradual queda da valorização e domínio do gênero masculino em relação ao feminino. Adicionamos as contribuições de Rezende et al (2017) que ressaltaram que o avanço da biotecnologia, da ciência e do capitalismo também influenciam nos novos formatos de família.

Assim, o discurso feminista vem alterando as organizações familiares de modo que há maior participação de pessoas do gênero masculino na vida dos filhos no que diz respeito aos cuidados e expressão dos afetos. Apesar de estar sofrendo questionamentos, o discurso patriarcal ainda está muito presente o que oferece uma representação de pai restrito ao sustento material e o uso do autoritarismo. Além disso, apresenta distanciamento afetivo e das práticas de cuidado dos filhos (PEREIRA, 2012).

Nossa noção de feminismo é como um "termo político, um questionamento do poder e da possibilidade de mudança” (LAGO, 2010, p. 15). Além disso, Roudinesco (2003) destacou que o feminismo corresponde a um projeto revolucionário de transformação da sociedade. 
Em nosso entendimento, apesar de imerso em uma cultura patriarcal mais rigorosa que a nossa, Freud (2006a) ofertou às mulheres de sua época um espaço de escuta e consideração de seus sintomas, de modo a comprovar que não se tratava de caprichos ou bruxarias, podemos observar isso em seus trabalhos presentes na obra Estudos sobre histeria.

Lago (2010) também destacou que há tensos e possíveis diálogos entre a psicanálise e os estudos sobre feminismo, sendo que os nós estão nas constituições das diferenças sexuais tendo como referência o falo.

Remetendo-se às classificações históricas do feminismo em ondas, Lago (2010) ensinou que a primeira onda corresponde aos séculos XIX e XX sendo caracterizada por reivindicações por cidadania (voto, trabalho e educação), são os chamados feminismos da igualdade de direitos. Já a segunda onda, está situada no pós-guerra, a partir dos anos 60 , para além da igualdade de direitos, buscou a afirmação das diferenças.

Assim, defendemos que o pensamento psicanalítico pode dialogar com o discurso feminista, mesmo havendo uma primazia do falo, visto que no pensamento lacaniano o entendemos como um significante e não como um poder sem limites imaginariamente associado ao homem.

Também é imprescindivel destacar que, na atualidade, há a possibilidade de uniões conjugais oficiais entre homossexuais e o fato de prescindirem do coito vaginal para que tenham uma criança sob seus cuidados, seja por adoção ou fertilização artificial. Também há a possibilidade de pessoas que não possuem união conjugal adotarem uma criança. Apesar dessas novas configurações, nenhuma dessas famílias questionam os interditos fundadores como proibição do incesto (ROUDINESCO, 2003). O que parece não questionar que haja pactos que regulem a civilização.

Roudinesco (2003) afirmou , a partir do final do século XIX, há uma prevalência de famílias com relações horizontais e fraternas, destacando que:

Para aqueles que temem mais uma vez sua destruição ou sua dissolução, objetamos, em contrapartida, que a família contemporânea, horizontal e em "redes", vem se comportando bem e garantindo corretamente a reprodução das gerações (ROUDINESCO, 2003, p. 197).

De qualquer modo, Roudinesco (2003) destacou que sempre os sujeitos se encontrarão com a questão da diferenciação sexual em suas constituições e que isso será do ponto de vista simbólico. Porém, vale ressaltar que Cossi e Dunker (2017) enfatizaram o 
último ensino lacaniano para destacar que a diferenciação sexual nunca será totalmente simbolizável, visto que há algo do real nesse processo.

Vale ressaltar que o modelo tradicional de família não garantia uma ausência de mal-estar. Kehl (2001) ressaltou que os sintomas estudados por Freud, em Viena, eram expressos por famílias nucleares conjugais, entendida ainda hoje como sendo a ideal. A família contemporânea vivencia um conflito de dívida com um modelo nuclear ideal, o peso dessa dívida impede que os adultos se autorizem dos riscos de se criar uma criança.

Soler (2016) destacou que na atualidade vivenciamos experiência ou ameaça de desenlace experimentado nas relações individuais, familiares e amorosas. Quanto a instabilidade das famílias, ressaltou que ocorrem devido a dois fatores: os fundamentos da família no casal amoroso que coloca a mercê dos desejos, pulsões e encontros; e a emancipação que o trabalho das mulheres assegura e que dá a elas meios de sobreviver fora do casamento. Vale destacar a citação:

A divisão do trabalho sexual significava o homem indo para fora e a mulher se encarregava de cuidar da casa, e é certo que isso assegurou a permanência da vida de muitos casamentos, embora eles fossem infernais. (SOLER, 2016, p. 8).

Portanto, entende-se que poder divorciar é algo que é importante para autonomia dos sujeitos, sobretudo para as mulheres. Porém, vale ressaltar que Roudinesco (2003) nos indagou sobre como realizar a transmissão da lei a partir dessas novas configurações.

Também vale ressaltar que o contexto atual do capitalismo financeiro apresenta relações com imperativos de sucesso, consumo e gozo. Há um nivelamento das antigas hierarquias que trabalhava especificamente na família em que a questão da autoridade está posta e onde se vê o fenômeno da criança tirânica. Disso resulta precariedade e angústia em que a criança cada vez mais é cercada por projeções narcísicas dos pais. (SOLER, 2016) . 


\section{LAÇOS DE FAMÍLIA E ESCOLA}

\subsection{As Famílias e suas funções}

... uma concepção da família fundada no assassinato do pai pelo filho, na rivalidade deste em relação ao pai, no questionamento da onipotência patriarcal, e enfim, na necessidade, para as moças, de se emanciparem sexualmente da opressão materna (ROUDINESCO, 2003, p. 61).

Introduzimos a questão da família e suas funções com a citação acima da obra $A$ família em desordem de autoria da psicanalista Elisabeth Roudinesco (2013), a quem nos referimos com frequência no capítulo três. No trecho ela discorreu sobre as relações familiares do ponto de vista freudiano que são atravessadas pelo conflito edípico, desse modo, é com Freud (1856-1939) que iniciaremos a mobilização sobre a noção de família.

Vale ressaltar que nosso objetivo é mobilizar as funções mais elementares que a família exerce para a civilização humana. Assim, Freud (2017b) nos ensinou que o ser humano possui a peculiaridade de ter uma longa fase de desamparo e dependência de outro ser humano. O bebê é trazido ao mundo menos pronto do que os filhotes de outras espécies, de modo que os perigos do mundo externo têm sua importância elevada.

As funções da família são entrelaçadas ao próprio processo civilizatório. Assim, Freud (2010a) ressaltou a importância de um grupo, ou de outro humano, que acolha outro ser humano, vale citar que:

O outro indivíduo adquiriu a seus olhos o valor de um colaborador, com o qual era útil viver. Ainda antes, em sua pré-história antropoide, ele havia adotado o hábito de construir famílias; os membros da família foram provavelmente os seus primeiros ajudantes (FREUD, 2010a, p. 61).

Em nosso primeiro capítulo referenciamos o pensamento freudiano para ressaltar que o amar é um modo de lidar com o sofrimento inerente de nosso condição humana, Freud (2010a) destacou que "Nada mais natural do que insistirmos em procurá-la no mesmo caminho em que a encontramos primeiro" (FREUD, 2010a, p. 39). Desse modo, a família é também para onde endereçamos nossos primeiros investimentos de amor. Porém, na família é esperado que o amor de cunho genital seja inibido e deslocado em sua meta para a ternura.

Para Freud (2010a), foi amor que inicialmente uniu os seres humanos, e não apenas a necessidade de divisão do trabalho como é proposto por outras teorias. No decorrer da vida 
espera-se que o ser humano amplie sua relação com a família e estabeleça novas uniões com pessoas antes desconhecidas.

É no contexto familiar que o ser humano comum constitui o que foi nomeado de Super-Eu, instância imprescindível para a vida em civilização. Para discorrer sobre isso, fazse necessário considerarmos o pressuposto freudiano de que a agressividade é um impulso humano que deve ser inibido, governado (FREUD, 2010a). Essa agressividade constitutiva é introjetada e mandada de volta, dirigida para o próprio $\mathrm{Eu}$, acolhida por uma parte deste é contraposta ao resto, o produto dessa operação foi nomeado por Freud (2010a) como Super$\mathrm{Eu}:$

...dispõe-se a exercer contra o Eu a mesma severa agressividade que o Eu gostaria de satisfazer em outros indivíduos. À tendência entre o rigoroso Super-Eu e o Eu a ele submetido chamamos consciência de culpa (FREUD, 2010a, p. 92).

Porém, vale destacar que "a vingativa agressão da criança é também determinada pela medida de agressão punitiva que espera do pai" (FREUD, 2010a, p. 101). Ou seja, para além da constituição dos impulsos agressivos da própria criança, tem-se uma resposta dela em relação ao que espera receber como punição da autoridade externa. Desse modo, o Super-Eu é formado por influências da constituição do sujeito e do rigor da educação que teve acesso.

$\mathrm{Na}$ família, o sentimento de culpa manifesta-se por meio do complexo de Édipo, criando o primeiro sentimento de culpa, ao se ampliar as relações o mesmo conflito prossegue em formas dependentes do passado (FREUD, 2010a).

Sendo assim, a noção freudiana de família está relacionada, para além da sobrevivência, com a necessidade humana de amor e de governar os impulsos agressivos com objetivo de ser possível a vida em civilização.

Partimos das considerações sobre família em Freud (1856-1939) e continuaremos em direção ao pensamento de Lacan (1901-1981). Cêra (2017), ao comentar a obra lacaniana, ressaltou que a família é entendida como uma instituição que é avessa do instinto, visto que família é o lugar onde o ser humano pode estabelecer e ordenar os instintos. É um lugar estrutural composto de posições e funções onde as ficções são construídas e onde serão ordenadas as identificações.

Sendo assim, destacamos que Lacan (2008b) defendeu a primazia do aspecto cultural em relação ao biológico ao discorrer sobre as famílias, argumentou que os humanos possuem a peculiaridade de "capacidades excepcionais de comunicação mental" 
(LACAN, 2008b, p. 7) e comportamentos que não correspondem aos instintos, assim não é possível reduzir o entendimento de família como um fato biológico.

Portanto, para Lacan (2008b) há primazia do cultural sobre o biológico e é essa abordagem com a qual concordamos. Vale destacar a seguinte uma citação:

\begin{abstract}
Em todos os grupos humanos, a família desempenha um papel primordial na transmissão da cultura. Se as tradições espirituais, a manutenção dos ritos e dos costumes, a conservação das técnicas e do patrimônio são com elas disputados por outros grupos sociais, a família prevalece na primeira educação, na repressão dos instintos, na aquisição da língua acertadamente chamada de materna (LACAN, 2008b, p. 9).
\end{abstract}

No trecho acima é defendido que a função primordial da família e de transmissão da cultura através da inserção no universo da linguagem "na aquisição da língua acertadamente chamada de materna" (LACAN, 2008b, p.9). Assim, ressaltamos a noção do Outro, sobre a qual discorremos com mais vagar no primeiro capítulo.

Soler (2016) ressaltou que há falsas camadas do desejo do Outro que existe antes do nascimento e só resta a criança interpretar esse discurso de quem encarna esse Outro. Voltolini (2011) nos ajuda a compreender isso quando afirma que o nascimento de uma criança depende de uma equação estabelecida no desejo de seus pais e essa condição faz com que a criança tenha que se deparar com as fantasias a partir da qual nasceu. E o ponto de partida dessas fantasias é a relação desses pais com seus próprios familiares de modo que temos uma complexa relação que terá suas particularidades no caso a caso.

Partindo do pensamento freudiano, Lacan (1998a) também ressaltou uma "prematuração específica do nascimento no homem" (LACAN, 1998a, p. 100) para destacar uma noção objetiva de inacabamento anatômico de modo a estar em uma situação de desamparo primordial em que depende totalmente de outro para sua sobrevivência. No momento inicial da vida, a criança está em posição suposta de total satisfação para o sujeito que está cuidando dela e a inserindo no campo da linguagem, esse é o lugar da função materna.

Alberti (2004) destacou que esse Outro que nos ampara no desamparo fundamental e nos apresenta ao mundo simbólico também deve ser barrado pela incompletude. O Outro primordial corresponde a quem efetua a função materna, Vitorello (2011) afirma que essa função diz respeito a inscrição das necessidades biológicas da criança no campo da linguagem. 
A instância que executa a função materna empresta a si mesma ao filho para que este possa se estruturar. Empresta seus desejos, linguagem e motricidade. Além disso, oferece à criança vivência de junção à instância tutelar, alienação, que é necessária para que o ser se estruture como sujeito (VITORELLO, 2011).

Porém, outra operação pode ocorrer de modo que a criança identifique que outros objetos são alvos de satisfações para esse exerce a função materna, outros objetos de satisfação para a mãe interditam a relação total do bebê, a execução dessa interdição é o que se compreende como função paterna.

A função paterna pode instaurar o desejo fundante porque abre espaço de falta para a criança se estruturar, Bernardino e Kupfer (2008) ressaltaram que para haver um espaço para operar a função paterna, faz-se necessário que a a função materna seja exercida de modo a não ser totalmente ausente nem presente, para que se abra um espaço de falta.

Portanto, a função paterna opera como um mediador entre a criança e o objeto de desejo. Apresenta para criança a realidade de que os objetos e pessoas não estão totalmente à sua disposição, é determinante e estruturante e envolve um ato de vontade e desejo, vai além da relação biológica estabelecida (PEREIRA, 2012).

Para além disso, Rezende et al (2017) valeram-se do pensamento lacaniano para destacar que a função paterna é um símbolo, um significante que barra o desejo de quem encarna a função materna. Quem encarna o pai, empresta seu nome para intervir na relação mãe-filho para que o sujeito se sirva dele. Esse nome é chamado de nome-do-pai que metaforiza o desejo da mãe. Para Roudinesco (2003) “o nome-do-pai designava o próprio significante da noção paterna, como inscrição no inconsciente da ordem simbólico" (ROUDINESCO, 2003, p. 103).

Castilho (2017) destacou que, na atualidade, o Outro não representa mais as figuras de autoridade e de identificações como na primeira metade do século XX. Referenciou o pensamento lacaniano para apontar que temos nomes-do-pai, no plural, indicando que não é mais o significante unívoco do nome-do-pai que opera na inscrição do sujeito na cultura.

Apesar de haver os impactos de aspectos sociais nas famílias, Roudinesco (2003) discorreu sobre algo universal que esteja presente na instituição família efetuou a seguinte afirmação:

... a instituição da família repousa na existência de uma diferença anatômica, supõe também, na mesma proporção, a existência de um outro princípio diferencial, cuja aplicação assegura, na história da humanidade, a passagem da natureza para a cultura. A proibição do incesto é portanto 
tão necessária à criação de uma família quanto a união de um macho com uma fêmea (ROUDINESCO, 2003, p. 15)

A partir da referência estrutural da instituição família, Roudinesco (2003) discorreu sobre as famílias de um modo simbólico onde a principal lei a ser transmitida é a lei do desejo, um sujeito se estrutura em função da filiação e sexuação de modo que a diferença sexual é colocada como enigma para todo ser humano, lembrando ainda que haverá sempre um a mais não simbolizável.

Atualmente, o processo de reprodução humana transcende a união sexual entre um macho e uma fêmea tendo em vista que no Brasil há possibilidades de reprodução assistida em laboratórios e da adoção de crianças, inclusive por casais homoafetivos ou por sujeitos que não tenham um par conjugal de modo a romper com uma imposição de família nuclear. Porém, entendemos que a questão da sexuação e das diferenças entre os sexos está presente na humanização dos sujeitos, independente do arranjo familiar que está inserido. Isto será posto para os sujeitos independente de que arranjo familiar tenha sido acolhido.

Além das funções ditas verticais da ordem do Outro, funções paternas e maternas, Kehl (2000) também ressaltou as funções nomeadas como fraternas, relacionadas ao outro, ao semelhante. Vale destacar que a função fraterna vai além de uma relação com os irmãos biológicos, trata-se de uma função ancorada nas relações horizontais com os pares, com o semelhante na fratria, que permite a cumplicidade para experimentar o proibido possibilitando se separar da autoridade parental com respaldo. É na circulação horizontal que se constitui os traços identificatórios secundários.

Vale destacar que a relação de cumplicidade e a suas transgressões organizadas coletivamente em nome de uma causa legítima pode renovar o pacto civilizatório. Isso é necessário para as mudanças na cultura e não correspondem necessariamente a delinquência ou perversão (KEHL, 2000).

Nesse contexto, o sujeito pode ampliar seus laços para além das relações familiares, constituir-se como sujeito e ser amparado em suas questões por um cúmplice que pode amenizar culpas pelos questionamentos. Além disso, é nas relações entre os pares que os sujeitos podem efetuar ações por mudanças nos pactos civilizatórios e nos aproximarmos de uma sociedade mais justa e igualitária.

Também Kehl (2000) fundamentou-se nos argumentos freudianos e lacanianos para demonstrar os aspectos de rivalidade e intrusão em relação aos irmãos. A autora detacou que no pensamento lacaniano o irmão, ou semelhante, está relacionado a uma identificação 
mental do sujeito com o pequeno semelhante, para além da relação com o espelho, tendo uma importante função na constituição do eu.

Lacan (2008b) discorreu sobre o que nomeou como um complexo de intrusão, quando ocorre a vida de uma outra criança na relação familiar, ressaltou que essa vivência de uma intrusão dependerá do momento que o mais velho vive em relação a sua constituição quando nasce outra criança. Vale ressaltar que não se trata de uma determinação, tendo em vista que entendemos sujeito como um ato de resposta (ELIA, 2010).

Nas palavras de Lacan (2008b): "o ciúme, em sua essência, representa não uma rivalidade vital, mas uma identificação mental" (LACAN, 2008b, p. 28). Então, notamos que o semelhante tem uma importante função para os sujeitos em seus processos de identificação e a rivalidade pode estar indicando um processo de identificação.

Porém, faz imprescindível destacar que a relação com o semelhante, assim como em todas as relações, é ambivalente é pode ser a origem também da segregação (BACKES, 2007).

A partir do exposto no decorrer deste ítem do presente capítulo, notamos que as famílias não são fundadas a partir da reprodução mas por lugares instituídos pelo fato de sermos seres de linguagem. Finalizamos ressaltando que, apesar do exposto, as famílias possuem suas singularidades, seus modos específicos de funcionar (REZENDE ET AL, 2017).

\subsection{Sobre os segredos familiares}

Neste ítem discorremos brevemente sobre os segredos familiares tendo em vista que Rezende et al (2017) destacaram que a família é fundada a partir de um segredo. Ela é uma encarnação do lugar do Outro e a análise tem a função de desfamiliarizar o sujeito, efetuar um desligamento.

Além disso, Cêra (2017) afirmou que há alguma coisa que não pode ser dita nos laços familiares, um excesso, um resto irredutível que se instala como segredo. Desse modo, a família é também produtora de um excesso que não é recoberto pelo enlace entre lei e desejo, trata-se de um excesso que é transmitido para além da delimitação do gozo e das identificações do masculino e feminino. 
Rosa (2009) pesquisou os aspectos e implicações dos não-ditos familiares no contexto de clínica com crianças. Ela identificou que situações que as famílias escondiam de modo voluntário das crianças tinham efeitos e eram manifestados por meio dos sintomas infantis. Assim, para além do não-dito constitutivo das famílias, há o que chamamos de segredos que são os não-ditos voluntários que são interdições que supostamente são comandadas pelo $\mathrm{Eu}$, mas que terminam por serem transmitidas de outro modo.

Geralmente, esses segredos geralmente são histórias familiares que revelam dores e/ou falhas de seus elementos, podendo operar de modo que o sujeito se apropria das informações escondidas sem articulação por meio da linguagem. Quando não são simbolízados esses não-ditos operam como mandatos, são apreendidos como estereótipos que ocupam o lugar da simbolização e funcionam como imperativos, destinos, a serem seguidos (ROSA, 2009).

Além disso, Soler (2016) destacou que o processo de identificação com o sofrimento dos pais ocupa um importante lugar na transmissão da história coletiva dos homens. Há transferência da dor entre gerações.

Desse modo, os segredos familiares terminam por causarem efeitos de sofrimento visto que não ofertam espaço para o sujeito ser ver com seu desejo, de modo que defendemos a importância de escuta do lugar dos antepassados nos laços de família.

Portanto, há um não-dito constitutivo nos laços familiares e há outros que podem causar sintomas e repetições transgeracionais. A escuta e oportunidade de colocar as questões em palavras podem efetuar possibilidades de ressignificações.

Prosseguiremos então em nosso capítulo, com a questão da adolescência.

\subsection{Adolescências e as famílias: um convite às reelaborações}

O tempo, o tempo é versátil, o tempo faz diabruras, o tempo brincava comigo, o tempo se espreguiçava provocadoramente, era um tempo só de esperas, me guardando na casa velha por dias inteiros; era um tempo também de sobressaltos, me embaralhando ruídos, confundindo minhas antenas, me levando a ouvir claramente acenos imaginários, me despertando com a gravidade de um julgamento mais áspero, eu estou louco! e que saliva mais corrosiva a desse verbo, me lambendo de fantasias desesperadas, compondo máscaras terríveis na minha cara, me atirando, às vezes mais doce, em preâmbulos afetivos de uma orgia religiosa: que potro enjaezado corria o pasto, esfolando as farpas sanguíneas das nossas cercas, me guiando até a gruta encantada dos pomares! que polpa mais exasperada, guardada entre folhas de prata, 
tingindo meus dentes, inflamando minha língua, cobrindo minha pele adolescente com suas manchas! (NASSAR, 2016, 97-103)

Iniciamos este tópico sobre adolescência com um trecho do romance Lavoura Arcaica, obra literária que traz o discurso de um adolescente em primeira pessoa, que nos ajuda a pensar sobre o tema da adolescência.

Trata-se de uma história narrada em primeira pessoa pelo personagem adolescente André que estabeleceu uma relação conjugal com a irmã, o romance tem o tema da família e das relações incestuosas como norteador.

No trecho notamos os sobressaltos que inferimos estarem relacionadas ao encontro com o corpo sexuado e em transformação, além do reencontro com a castração "me despertando com a gravidade de um julgamento mais áspero, eu estou louco!" (NASSAR, 2016, 97-103).

Assim, iniciamos ressaltando que o conceito de adolescência não é originalmente trabalhado na psicanálise freudiana, mas a psicanálise muito pode contribuir (ALBERTI, 2004; BRIOLE, 1994). O que Freud (2017a) discorreu foi sobre a puberdade, destacou que além de novos impulsos próprios desse momento da vida, os impulsos agressivos dos primeiros tempos da infância são novamente despertados, surgindo intenções agressivas e destrutivas. Outra ponto levantado por ele é que, até então, as satisfações sexuais eram autoeróticas e na puberdade elas encontram objeto sexual e metas diferentes.

Ressaltando as contribuições da psicanálise para o que nomeamos como adolescência, Rosa e Vicentin (2010) ressaltaram que esta corresponde a um trabalho desencadeado pela puberdade, de modo que não é caracterizada por comportamento ou personalidade. Bairrão (2011) também destacou que o adolescer não corresponde a uma etapa natural de um suposto desenvolvimento humano, mas uma difícil equação em que sujeito vai ocupar um lugar de adulto.

Portanto, cada sujeito dito adolescente fará seu trabalho a qual é convocado tendo em vista suas particularidades e seu contexto. E de qual trabalho se trata?

Para discorrermos sobre a questão colocada, faz-se importante compreender o papel da elaboração das perdas e separação da autoridade paterna, há a perda do corpo infantil e encontro com o real de que somos seres sexuados. Mas, para que haja separação se faz imprescindível uma presença, assim os adolescentes utilizarão suas referências mesmo que seja para se contrapor à elas (ALBERTI, 2004). Desse modo, para haver uma separação é 
necessário que primeiro tenha havido uma alienação ao desejo do Outro (VOLTOLINI, 2011).

O trabalho então a qual o sujeito é convocado a fazer é o de separação dos pais, ou substitutos, imaginários. Os sujeitos utilizarão as direções, indicativos e determinantes que tiveram no decorrer de toda a sua vida para efetuar suas escolhas. Trata-se de uma escolha do sujeito, ou seja, ele pode atravessar ou não o desligamento da autoridade parental. Esse trabalho exige um enorme esforço e implica um encontro com o sexo, o encontro com o posicionamento em relação ao fato de sermos sexuados (ALBERTI, 2004).

Esse encontro com o sexo é com um novo objeto sexual que até então era autoerótico. Trata-se de um momento de redescoberta do objeto que a criança renunciou no final do Édipo que teve como consequência o recalcamento do objeto parental (LACADÉE, 2012).

Vale ressaltar que, o processo de separação deve ser um trabalho efetuado pelos dois lados, do sujeito e de suas figuras de autoridade parental. Briole (1994) também destacou que, as figuras parentais, e outras figuras que ocupam seus lugares, podem projetar as suas próprias errâncias nesse sujeito dito adolescente.

Para Castilho (2017), a errância é efeito de um sujeito que não se reconhece no desejo do Outro, sem orientação de um espaço corporal e de uma temporalidade. Vale apresentar a citação:

As particularidades familiares não são mais suficientes para tratar o real em jogo, para fazer escolhas, para ir ao encontro do Outro sexo (CASTILHO, 2017, p. 166).

Isso implica em que os sujeitos ficam sem referências para efetuar o trabalho de separação.

Vale ressaltar que a errância não deve ser confundida com o ser nômade, ou seja, a um modo de vida em movimento e com referências. A errância diz respeito a uma perda de um lugar no desejo do Outro. Neste contexto, notamos que as perturbações psíquicas que se queixam sobre os sujeitos adolescentes - queixam-se famílias, escolas e outros condensam nos registros do corpo, no qual os atos dominam em relação a palavra e evidenciam uma pobreza dos processos de simbolização (CASTILHO, 2017) .

$\mathrm{Na}$ atualidade constatamos abalos de referências com fragilização do laço e procura de novas identidades para fazer grupo, os laços se dão em termos de demanda ao consumo 
onde as referências simbólicas estão enfraquecidas. Esse enfraquecimento é explicado devido ao declínio da função paterna (BRIOLE, 1994).

Além disso, Ramon et al (2016), valendo-se do pensamento de Jacques-Alain Miller (2015 apud RAMON ET AL, 2016), destacaram que o discurso capitalista coloca o consumo como lugar de completudo imaginária. Isso traz como efeitos o saber sendo depositados em máquinas e não no Outro.

O modo de gozo da atualidade está relacionado à lógica do consumo de objetos, medicamentos, substância psicoativa ou outros que podem entrar em um lugar de completude imaginária. Notamos os efeitos disso na forma de que alguns adolescentes fazem laço, roubando, fraudando, furtando dentre outros atos infracionais. Desse modo, o adolescente testemunha um mal-estar que diz respeito ao campo social, familiar e de seu corpo (BRIOLE, 1994).

Retomamos que, para Alberti (2004), o sujeito é convocado a efetuar a separação dos pais imaginarizados e idealizados em um momento que convencionamos nomear adolescência. $\mathrm{O}$ sujeito se depara com o furo do Outro, a incompletude. Tal situação pode ter efeito de intenso sofrimento.

Mas, valendo-se da função fraterna, os sujeitos podem se articular e efetuar ações de questionamentos da sociedade, visto que "O adolescente é sempre de sua época, e até mesmo antecipa a que está por vir" (BRIOLE, 1994, p. 12).

Para ilustrar tal afirmação, remetemo-nos às ocupações de mais de 200 escolas durante cerca de 60 dias no Brasil, que tiveram como protagonistas estudantes secundaristas. Isso ocorreu entre o final de 2015 e início de 2016 e foram atos de transgressão contra o governo e legitimados pela comunidade e familiares dos alunos (GOHN, 2017). Sobre as referidas ocupações, também Castilho (2017) destacou que "agora que a sociedade está passando por rápidas mudanças de valores em razão do declínio dos ideais, vemos os adolescentes lutando por eles" (CASTILHO, 2017, p. 173).

Assim, ao questionar o Outro e seu furo, os sujeitos podem deslocar suas agressividades para a militância política e até questionarem os pactos civilizatórios. Portanto, apesar das condições postas, há também um trabalho dos sujeitos que podem, inclusive, subverter a ordem.

Efetuadas as mobilizações sobre o que se convém nomear como adolescência, partiremos para um novo ítem de nosso capítulo que trata da escola. 


\subsection{A escola e suas relações}

Domingo, 17 de fevereiro

Amanhã vão começar as aulas da Escola Normal. Tenho certeza que vou empacar no segundo ano como aconteceu no primeiro. Eu fico triste de pensarem que sou burra sem ser; mas que hei de fazer? Nem me queixo mais. Mamãe quando compra algum livro é sempre para os dois, para mim e Renato. Ele não gosta de estudar e não deixa também que eu estude; ficamos brigando o tempo todo até eu desistir. Se eu pego num livro ele logo diz: "É este que eu vou estudar". Se não lhe dou o livro não adianta, porque ele me atormenta o dia inteiro até eu cansar e deixar. Além disso, tendo a Chácara para ir todos os dias e os serviços de casa para fazer, não me sobrará muito tempo para estudar.

Meu pai diz que se eu prestasse atenção às aulas eu aprenderia. Sei disso muito bem, mas tive a infelicidade de cair na roda das meninas mais vadias da Escola. Elas não deixam a gente sentar nos bancos da frente nem prestar atenção às lições. Já fomos desde o primeiro ano consideradas vadias e tem de ser assim até o fim. Também que me importa? A Escola é tão alegre e eu passo ali os dias tão feliz que não faz mal.

Amanhã já tenho de começar a escrever diariamente a carta ou redação da Escola e copiar o exercício de Ornamentos da mémoria. Nós na Escola poderemos sair sem saber Geometria, Francês, História e tudo mais; mais sairmos sem saber escrever eu duvido. Eu gosto muito de escrever; é a única coisa que eu cumpro os deveres da Escola. Também Seu Sebastião depois da aula fica na porta à espera, e todas temos de ir saindo e entregando o exercício e a redação. Nenhuma tem coragem de afrontar o professor de Português, porque vemos que ele se esforça o mais que pode em nosso benefício. (MORLEY, 2016, p. 143)

O trecho acima é de um capítulo da obra Minha vida de menina. Trata-se de um diário de uma adolescente escrito entre 1893 a 1895 em Diamantina/MG que foi publicado pela autora em 1942 sob o pseudônimo de Helena Morley. No capítulo que retrata o dia 17 de fevereiro de 1895, Helena escreve sobre sua relação com a escola, com o professor, com os colegas e com a arte de escrever.

Sobre essa relação com o professor, Freud (2006c) em sua obra Algumas reflexões sobre a psicologia do escolar enfatiza que o professor é uma figura substituta ao pai que seria a imagem mais importante e pertubardora da vida institiva tando do menino quanto da menina, todas as ambivalências investidas ao pai poderiam também serem investidas ao professor, nas palavras do autor:

Minha emoção ao encontrar meu velho mestre-escola adverte-me de que antes de tudo, devo admitir uma coisa: é dificil dizer se o que exerceu 
mais influência sobre nós e teve importância maior foi a nossa preocupação pelas ciências que nos eram ensinadas, ou pela personalidade de nossos mestres. E verdade no mínimo, que esta segunda preocupação constituía uma corrente oculta e constante em todos nós e, para muitos, os caminhos das ciências passavam apenas através de nossos professores. Alguns detiveram-se ao meio caminho dessa estrada e para uns poucos -porque não admitir outros tantos?- ela foi por causa disso definitivamente bloqueada. (FREUD, 2006c, p. 247)

Em seu diário, Helena Morley destacou a relação com a escrita e com o que seu professor a transmitiu à sua revelia, transmitiu um esforço que é admirado por Helena que pôde ter sido uma importante contingência na contituição de seu prazer pela escrita.

Outro ponto também refletido por Freud (2006c) é que a escola deveria proporcionar não apenas uma supressão de condutas por meio de punições, mas oportunidades de sublimação. A atividade intelectual é um modo de sublimação a qual podemos nos recorrer, sendo a escola espaço de excelência para tal atividade.

Esse lugar que a escola pode proporcionar, de sublimação, também é discorrido na obra Três ensaios sobre a teoria da sexualidade na qual é destacado que o período de latência dos impulsos sexuais, ou seja, uma certa inibição das manifestações sexuais que ocorriam até então, podem ser sublimadas na atividade intelectual (FREUD, 2017a).

Tendo como referência o pensamento lacaniano, Pereira (2005) vai além do entendimento do professor como substituto da figura do pai ressaltando a necessidade do lugar do discurso do Outro para que ocorra a aprendizagem no contexto escolar e, assim, o educador pode ocupar "uma importância especial, pois torna-se a figura a quem serão endereçados seus interesses" (PEREIRA, 2005, p. 96).

Também vale ressaltarmos que a escola é o lugar onde as funções fraternas, pensadas por Kehl (2010), instauram-se visto a relação do sujeito com os colegas, com os pares, propiciando as identificações secundárias.

Até o momento, discorremos sobre as contribuições psicanalíticas a respeito da escola ressaltando suas relações que podem vir a ocupar para o aluno o lugar do Outro e do outro (semelhante). A seguir, destacaremos aspectos sociológicos a partir das contribuições do teórico da educação Charlot (2014) que em seus trabalhos se posiciona em diálogo com a psicanálise.

Charlot (2014) se remeteu ao fenômeno da globalização para entermos a educação na atualidade, ressaltou que ela vai além de um processo socioeconômico visto que traz consequências culturais. Se houver um rompimento com o compromisso de exploração e lucros exorbitantes, ou seja, o neoliberalismo, a globalização pode ser uma saída para a 
solidarização entre os povos tendo em vista que cria uma interdependência entre os seres humanos.

O neoliberalismo tem influenciado a relação dos seres humanos com o saber, este tem ocupado um lugar utilitarista se distanciando da função de prazer de modo a difundir a educação como uma mercadoria, sendo ofertadas aprendizagens mecânicas e superficiais (CHARLOT, 2014). Uma educação utilitarista pode não proporcionar que o aluno enderece à escola sua curiosidade e prazer ao próprio ato de estudar, aniquilando o sujeito.

Para Charlot (2014) a vivência da cidadania requer uma comunidade escolar regida pela lei e pela autoridade, não pela vontade do mais forte e arbitrariedade, assim como entendemos que ocorre na lógica neoliberal na qual o mais forte foi substituído pelo que tem mais dinheiro. Remetemo-nos a Freud (2010a) quando discorreu sobre a civilização humana e a necessidade de haver regulações, lei simbólica, que possibilite a vivência em sociedade.

Para pensar sobre uma possível subversão dos preceitos neoliberais no contexto escolar, retomamos a teoria dos quatro discursos lacanianos comentados por Pereira (2005) que mencionamos em nosso segundo capítulo, a saber: discurso do mestre, do analista, do universitário e da histérica. Pereira (2005) destacou que o professor pode ter a posição do discurso de mestre e conseguir abertura no discurso desde que não se enlace de um modo cristalizado, ou seja, desde que permira giros em seus discurso.

Corrobora com esse pensamento o teórico Charlot (2014) quando afirmou que a escola é um espaço de palavras que possibilita a objetivação do mundo e o distanciamento com ele, de modo a ofertar possibilidade de ressignificação. Esse distanciamento necessário também nos remete ao que Agamben (2009) entendeu por sujeito contemporâneo, assim como discorremos no capítulo três.

Ressaltamos novamente que a psicanálise aplicada à educação pressupõe considerarmos os aspectos inconscientes dos envolvidos, considerarmos as particularidades. Charlot (2014) apontou a necessidade de encontrarmos um ponto de equilíbrio entre o universalismo e o particular nos planejamentos da educação escolar, assim como propôs Freud (2010b) em seu texto Considerações atuais sobre guerra e morte.

Além disso, entendemos que o mal-estar do corpo sexuado e da vida em civilização poderá ser endereçado às instituições que representam o Estado, entre elas a escola, visto que elas podem encarnar para os sujeitos figuras de lei simbólica com efeito civilizador e 
pacificador frente aos conflitos (VITORELLO, 2011). Desse modo, a escola e os educadores podem estar neste importante lugar simbólico para os sujeitos.

Portanto, a escola é, para além dos processos pedagógicos de ensino do conhecimento historicamente acumulado, um lugar de subjetivação e transmissão. A psicanálise e seus pressupostos, em parceria e diálogo com outros saberes, pode nos ofertar possibilidades de subversão das questões sociais ditas determinantes no contexto escolar. 


\section{ASPECTOS METODOLÓGICOS}

Inauguramos o presente capítulo retomando que nosso embasamento teórico é da psicanálise freudo-lacaniana com contribuições da $\mathrm{AD}$ pecheuxtiana. Vale destacar que ambas são teorias que já são métodos de pesquisa, mas, neste capítulo, discorremos com mais vagar sobre seus aspectos metodológicos entrelaçados aos objetivos de nossa pesquisa.

Sendo assim, ressaltamos que um importante aspecto das pesquisas em $\mathrm{AD}$ o e psicanálise é que o pesquisador, que analisará questões ideológicas ou inconscientes do discurso, também sofre as determinações de seu inconsciente e é assujeitado ideologicamente (DUNKER; PAULON; MILÁN-RAMOS, 2017).

Isso traz implicações de que o sujeito pesquisador necessita efetuar constantes autoquestionamentos de modo a efetuar a tentativa de distanciamento. Caso trabalhe a partir da psicanálise, é recomendado que o pesquisador também esteja finalizado ou em processo de vivência de análise pessoal. Sobre isso, vale destacar o pensamento de Freud (2006d) que recomendou, para o contexto clínico, que o analista tenha vivenciado a análise pessoal, caso contrário:

Cairá facilmente na tentação de projetar para fora algumas das peculiaridades de sua própria personalidade, que indistintamente percebeu, no campo da ciência, como teoria validade universal; levará o método psicanalítico ao descrédito e desencaminhará os inexperientes (FREUD, 2006d, p. 131).

Efetuamos então uma transposição dessa recomendação para as escutas com fins exclusivos de pesquisa para que assim proporcione um modo de minimizar possíveis projeções do pesquisador. Tendo isso em vista, continuaremos nosso percurso metodológico.

\subsection{Fundamentos metodológicos}

Iniciaremos este tópico ressaltando o paradigma indiciário, vale esclarecer que um paradigma é, basicamente, um princípio regulador de teorias. Laureano (2008) defendeu que a psicanálise e a $\mathrm{AD}$ pecheuxtiana são filiadas ao paradigma indiciário, este foi sistematizado por Ginzburg (2016) a partir dos estudos do crítico de arte Morelli (1972 apud GINZBURG, 2016) que identificava a autenticidade de obras de arte por meio de 
pormenores das pinturas como: orelhas, dedos, unhas, entre outros detalhes despercebidos, mas sempre em relação a obra em conjunto.

Esses traços marginais foram entendidos como sendo características individuais do artista, tão peculiares, que fugiam do controle do mesmo e transcendiam ao movimento estético cultural ao qual o artista se filiava (GINZBURG, 2016).

A partir disso, Ginzburg (2016) efetuou relação do referido método com o de Sherlock Holmes, personagem criado pelo autor Arthur Conan Doyle (1969 apud GINZBURG, 2016) e do método de Freud (1914 apud GINZBURG, 2016), em que as pistas seriam indícios para uma verdade. Sobre a obra freudiana, Ginzburg (2016) destacou:

...pormenores normalmente considerados sem importância, ou até triviais, "baixos" forneciam a chave para aceder aos produtos mais elevados do espírito humano (GINZBURG, 2016, p. 150)

Portanto, o paradigma indiciário engloba teorias que buscam analisar um fenômeno a partir de indícios geralmente imperceptíveis e negligenciados. Tais pormenores, por vezes considerados triviais, podem ser a chave na resolução de uma questão visto que constituem pistas que nos ajudam em seu desvelamento (GINZBURG, 2016).

Efetuada essa localização paradigmática de nossa pesquisa, destacamos que a pesquisa em psicanálise classicamente envolve a fala, a oralidade em primeira pessoa e em situação de transferência, a partir disso eram construídos casos clínicos (DUNKER; PAULON; MILÁN-RAMOS, 2017).

Mas, defendemos a possibilidade da escuta e pesquisa a partir da psicanálise em situações não clínicas. Para isso, fundamentamo-nos em Rosa (2004) ao afirmar que o sujeito do inconsciente se expressa em todos os enunciados, de modo que atravessa qualquer discurso. Sendo assim, sua apreensão pode ser realizada em função de um tema específico desde que haja a consideração e manejo da transferência.

Rosa (2004) apontou que a pesquisa em psicanálise se define pela maneira de formular as questões. Retomando que o participante da pesquisa é um sujeito do inconsciente, recomenda-se que a entrevista deve ser manejada de modo a propiciar que o entrevistado se atente para o seu discurso, assim a vivência como participante pode também ter efeitos de intervenção.

Efetuadas as ressalvas sobre as amplas possibilidades da escuta psicanalítica, prosseguiremos: 


\subsection{Condições de produção e participantes}

Iniciaremos este tópico destacando a primeira contribuição da $\mathrm{AD}$ para a nossa pesquisa que diz respeito às condições de produção. Para Orlandi (2015), as condições de produção são os sujeitos e a situação da pesquisa que interferem no que o sujeito nos dirá. Assim, apresentaremos a seguir as condições de produção das entrevistas realizadas com quatro participantes de idades variando entre treze e quatorze anos.

Esclarecemos que entrevistamos dez sujeitos adolescentes que frequentavam uma escola estadual do interior paulista que possui quinhentos e cinquenta e oito alunos, está localizada na periferia do município e e oferece o ensino fundamental I e II. Para os fins da nossa pesquisa, optamos por analisar quatro das entrevistas realizadas e, no decorrer deste capítulo, justificaremos tal decisão.

Nossa mediação com a escola ocorreu por meio da vice-diretora, esta escolheu para participar da pesquisa adolescentes dos oitavos e nonos anos do ensino fundamental que apresentavam diversas configurações familiares. Não houve critérios de exclusão relacionados a algum atraso escolar ou enfermidade.

Consideramos o fenômeno da transferência, pressuposto psicanalítico, como uma condição de produção. Destacando a transferência selvagem (LACAN, 2005a) - conforme discorremos no primeiro capítulo - realizamos uma primeira reunião na biblioteca da escola com os participantes e a vice-diretora. Assim, foi uma oportunidade de os adolescentes conhecerem a pesquisadora e iniciarem uma relação.

Vale mencionar que obtivemos a informação de que a biblioteca não possuia profissional para mantê-la, sendo gerenciada pelo Grêmio estudantil que se responsabiliza ainda pela organização e empréstimos de livros. Também observamos que os sinais de entrada e saída das aulas eram músicas, escolhidas pelos alunos e que variam semanalmente. Desse modo, podemos inferir um lugar em que os pedidos dos alunos são parcialmente acolhidos.

$\mathrm{Na}$ referida primeira reunião, apresentamo-nos e esclarecemos os objetivos da pesquisa e os Termos de Consentimento Livre e Eslarecido (TCLE-Anexo I) e Termos de Assentimentos (TA-Anexo II). Posteriormente, a vice-diretora entregou os termos aos tutores dos participantes e explicou do que se tratava a pesquisa.

Retomamos que o manejo da transferência no contexto clínico corresponde, inicialmente, em efetuar um silenciamento de si para tentativa de ocupar o lugar de endereçamento, a uma posição em que não se coloque como mestre ou orientador de 
questões. Esse lugar é ocupado porque o sujeito procura o analista devido às suas queixas e supõe que este saiba sobre seu sofrimento (NÁSIO, 1999).

$\mathrm{Na}$ pesquisa por meio de entrevista semiestruturada em que se tem objetivos específicos que não o tratamento, isso é invertido já que a entrevista ocorre devido ao pedido do pesquisador. Assim, o pesquisador não ocupa a priori para o participante o lugar de suposto saber e se faz necessário um manejo para que haja a efetiva participação (ROSA; DOMINGUES, 2010).

Vale ressaltar que consideramos efetiva a participação quando, ao escutarmos os adolescentes, identificássemos elementos que nos indiciassem posição subjetiva mais próxima possível do que Násio (1999), a partir do pensamento lacaniano, nomeou como de implicação subjetiva. Para que isso ocorra, é necessário que a transferência esteja operando.

A posição de implicação subjetiva, no contexto clínico, corresponde a uma responsabilização e envolvimento do sujeito frente a suas queixas de modo que esteja mais próximo de um autoquestionamento do que de culpabilização aos fatores externos. Não se trata também de culpabilização do sujeito e sim de ele pensar sobre o que tem a ver com seus sintomas, no caso, de seus discursos frente ao significante família.

Para que essa posição tenha se instaurado entendemos que a transferência estava posta, visto que havia um terceiro a qual o adolescente pôde endereçar suas posições subjetivas em relação às questões apresentadas.

Assim, decidimos apresentar nesta dissertação a análise dos discursos de quatro dos adolescentes escutados visto que seus discursos indicaram algo de uma implicação subjetiva e transferência ao responderem nossas questões, ou seja, questionavam o que diziam.

Durante as entrevistas, manejamos para que pudéssemos propiciar uma abertura no discurso, ou seja, tentamos não ocupar o lugar do discurso do mestre, para assim os adolescentes nos endereçar suas posições subjetivas.

Tendo efetuado os apontamentos acima, informamos que as entrevistas foram agendadas em duas manhãs, sendo que entrevistamos quatro adolescentes em uma manhã de sexta-feira e seis na segunda-feira seguinte. Estavam no horário de aula e saíram da mesma para participar da entrevista. 
Havia sido combinado, com eles e com a vice-direção que as entrevistas ocorreriam na biblioteca, mas de fato foram realizadas em uma sala de informática porque a biblioteca estava sendo usada para aulas. A sala de informática estava desativada, visto que não havia internet e nem profissionais para cuidarem do espaço. Foi necessário limpá-la rapidamente antes das entrevistas porque havia acúmulo de pó.

Efetuamos então os esclarecimentos acerca das condições de produção e uma breve apresentação dos participantes que será melhor realizada no capítulo seis. Sendo assim, seguiremos o trabalho apresentando como ocorreram as entrevistas individuais.

\subsection{Entrevistas: o momento da escuta}

Para acesso aos discursos dos adolescentes foram efetuadas dez entrevistas utilizando questões abertas e escuta ativa. As entrevistas foram manejadas de modo a mobilizar o questionamento dos participantes sobre o tema. A reunião anterior com eles foi importante para a apresentação da pesquisadora e do projeto, bem como manejo da 1 transferência.

As entrevistas continham dezenove perguntas cada uma e seguiram um roteiro de perguntas (Anexo III) previamente elaboradas e aprovadas pelo Comitê de Ética e Pesquisa (CEP). As questões foram baseadas na literatura pesquisada sobre o assunto e elaboradas de modo que encorajassem os sujeitos a narrarem as suas histórias familiares, a conceituarem família, a discorrerem sobre o que pensam sobre a família na atualidade e a relação com a educação formal.

Ao início de cada entrevista, destacamos que não se tratava de uma situação de avaliação, ou seja, não havia respostas certas ou erradas. As entrevistas foram gravadas e posteriormente transcritas.

Vale destacar que Bleger (1980) afirmou que a entrevista propicia uma investigação mais ampla e profunda do fenômeno. A técnica da entrevista possibilita contato direto com os participantes relacionados ao fenômeno a ser investigado, e pode ser um instrumento importante na pesquisa que tenha embasamento teórico psicanálitico, já que oferece um espaço de escuta do sujeito participante.

Assim como Rosa (2004), Bleger (1980) também nos alertou que a entrevista elaborada com propósito de levantamento de dados para pesquisa necessita de um entrevistador que desperte o interesse no entrevistado, visto que o mesmo não está participando devido à sua própria demanda. 
Desse modo, manejamos as entrevistas de modo a acupar um lugar de silenciamento na qual os adolescentes pudessem se colocar. Houve entrevistas que apresentaram questões intensamente conflituosas de modo que foi necessário também uma posição acolhedora, ou seja, de reconhecimento frente ao sofrimento apresentado.

Prosseguimos então, para nosso próximo é último tópico deste capítulo.

\subsection{Constituição do corpus e análise dos resultados}

Iniciaremos este tópico mobilizando a noção de corpus, advinda da contribuição da AD pecheuxtiana. O corpus corresponde ao material a ser trabalhado na pesquisa, Assolini (2003) destacou que a delimitação do corpus ocorre com a própria análise e a partir de recorte dos dados efetuados em razão dos objetivos da pesquisa. Sobre isso, ressaltamos uma citação de Orlandi (2015):

... a construção do corpus e a análise estão intimamente ligadas: decidir o que faz parte do corpus já é decidir acerca de propriedades discursivas. Atualmente, considera-se que a melhor maneira de atender à questão da constituição do corpus é construir montagens discursivas que obedeçam critérios que decorrem de princípios teóricos da análise do discurso, face aos objetivos da análise, e que permitam chegar à sua compreensão (ORLANDI, 2015, p. 62).

Sendo assim, o corpus foi contituído a partir de recortes realizados no material bruto (entrevistas transcritas na íntegra), ressaltando que selecionar os recortes já constituiu um gesto de interpretação (ORLANDI, 2015).

Rosa e Domingues (2010) identificaram que a análise de dados na pesquisa psicanalítica deve ser orientada pela escuta e transferência instrumentalizada do pesquisador na relação com o material. Tendo isso em vista, nosso primeiro gesto de análise foi o contato com as entrevistas transcritas, bem como escuta dos áudios gravados.

Foram efetuadas escutas flutuantes dos áudios e leituras flutuantes das entrevistas transcritas. O que Freud (2006d) recomendou para a condução de um tratamento, adaptamos para a escuta no contexto da pesquisa acadêmica e para a leitura das entrevistas transcritas. Nas palavras do autor:

A técnica, contudo, é muito simples. Como se verá, ela rejeita o emprego de qualquer expediente especial (mesmo de tomar notas). Consiste simplesmente em não dirigir o reparo para algo específico e em manter a 
mesma 'atenção uniformemente suspensa' (como a denominei) em face de tudo o que se escuta (FREUD, 2006d, p. 125).

Então, contrariando as análise conteudistas, a leitura do texto das entrevistas perpassou essa atenção uniformemente suspensa, para depois efetuar relação com os objetivos da pesquisa. Esse trabalho possibilitou a delimitação de recortes que constituiu nosso corpus.

Os recortes foram estabelecidos após as análises da cadeia significante onde o sujeito apareceu por meio de indícios como: atos falhos, repetições, negações, contradições, chistes entre outras manifestações do inconsciente, assim como sistematizou Bartijotto (2014).

Nesse processo, foram escolhidas sequências discursivas de referência que correspondem a trechos superiores às frases e que conduziram as apresentações das análises (COURTINE, 1981 apud ASSOLINI; DORNELAS, 2016).

Além disso, os recortes e sequências discursivas de referência foram analisados tendo em vista a totalidade de cada entrevista e as condições de produção delas. Vale destacar que a descrição e análise dos recortes não foram sucessivos, ocorreram em alternância entre as duas ações diferenciando dos procedimentos de análise das ciências positivas (PÊCHEUX, 2015).

Sendo assim, seguiremos com as análises dos discursos dos adolescentes escutados. 


\section{O QUE OS ADOLESCENTES ESCUTADOS FALAM SOBRE OS LAÇOS DE FAMÍLIA E ESCOLA?}

Finalmente apresentaremos as análises dos discursos de nossos adolescentes escutados. Discorremos sobre o discurso de quatro adolescente que ocupam o que consideramos mais próximo de uma implicação subjetiva e de transferência.

Vale lembrar que analisamos os discursos separadamente, um a um, de modo a manter posição da particularidade de cada participante além de efetuarmos as análises dos recortes em função da totalidade do discurso.

Além disso, faz-se imprescindível ressaltar que, com o objetivo de manter os anonimatos dos participantes, criamos nomes fictícios para cada um deles.

Portanto, iniciaremos, nossa exposição.

\section{1 João}

Nossa primeira apresentação corresponde ao adolescente de treze anos a quem atribuímos o nome de João. No momento da entrevista, ele estava no oitavo ano do ensino fundamental II e residia na escola com sua família porque seu pai é caseiro da escola, além de trabalhar como motorista.

A mãe de João trabalhava com os afazeres domésticos. Ele possui um irmão mais novo de sete anos e ele nos relatou que a mãe parou de trabalhar remuneradamente quando o irmão nasceu.

Iniciaremos nossas análises com a apresentação de um primeiro recorte:

\section{JOÃO: RECORTE 1}

... eu não sei muito sobre as famílias... é... antigas, a minha vó me contava como era a dela, e... pelo o que ela me contava a dela é muito diferente da minha, por causa que a dela... é... a dela sempre foi muito desunida. Desde os dez anos cada um foi para um lado, teve que casar muito cedo por que na época dela era casamento arranjado ai tiveram que arranjar um noivo para ela, ai ela teve que sair de casa aos treze anos por que ela iria casar, com treze anos, e... a familia dela sempre foi muito desunida e apesar de que a minha não é tão unida quanto era para ser, ela é mais do que a da minha vó e... a família da minha vó era muito mais... é... eu não sei como eu 
posso dizer mas era uma... tipo, eles tinham mais regras do que a minha, é... eles sempre tiveram muito mais regras. A minha é um pouco...é ...eu poderia dizer que é um pouco desregulada, por que... não tem muita regra na minha família. (SUJEITO JOÃO)

No recorte 1 apresentamos a resposta de João quando perguntamos se ele identifica diferenças entre a sua família e seus antepassados. Destacamos a regularidade da expressão tem. Ele ressaltou que nas gerações anteriores de sua família, a conjugalidade era algo obrigatório, arranjado pelos pais: ela teve que sair de casa aos treze anos por que ela iria casar, com treze anos. Ressalta-se que ele enfatizou os treze anos, mesma idade que ele de modo que inferimos que está efetuando uma comparação.

A partir do constante uso da expressão ter que, e considerando que ele está implicado em sua fala, podemos inferir que ao enunciar a expressão tem, há uma implicação de algo dele, de modo que entendemos que ele está submetido também a alguma obrigação, assujeitado a uma lei, mesmo que de modo diferente do que de sua avó. Essa lei em comum, entendemos como do desejo, instaurado nos processos de humanização e de identificação (NÁSIO, 1989) .

Em sua condição de adolescência ele demonstra uma posição de questionamentos (ALBERTI, 2004). Inferimos que localizou diferenças entre seus antepassados e sua atual família: eles tinham mais regras do que a minha, é... eles sempre tiveram muito mais regras. A minha é um pouco... é ...eu poderia dizer que é um pouco desregulada, por que... não tem muita regra na minha.

Destacando que o adolescente é de sua época (BRIOLE,1994), inferimos que na última sequência discursiva apresentada, está sendo apresentada as marcas do sujeito do que ele identifica de sua época, ou seja, que as famílias estão desreguladas, por que... não tem muita regra na minha.

Entende-se que o contexto da avó de João era de submissão à uma figura inquestionável, no que se refere a viver uma união conjugal oficial. Sua avó já foi enviada para casamento de modo que não estava colocada em uma posição de adolescente em sua família, mas já como uma adulta.

Já João pode escolher seu par, mas enuncia que as famílias atuais carecem de ofertar regras, ressaltando uma excessiva permissividade assim como destacou Soler (2016). 
Apesar de ele mencionar que na família de sua avó tinham mais regras o significante desunido emergiu ao falar tanto sobre a família da avó, quanto de sua família. Ou seja, ter regras rígidas não garantiu o que ele nomeou como união da família. Parece que essa desunião foi transmitida. Além disso, também podemos inferir que ele apresenta o imaginário de que família tem que ser unida, visto que a dele deveria ser.

Continuaremos então com nossas análise, eis o segundo recorte:

\section{JOÃO: RECORTE 2}

é... eu poderia dizer que da minha família ela é a pessoa que mais passo tempo junto, é a pessoa que eu mais vejo e também por que eu acho que eu e minha mãe temos personalidades muito parecidas, a gente é muito igual, a gente...eu sou uma pessoa muito sensível a minha mãe também, e... a gente também é muito... como é que fala? A gente é muito medroso, eu sou uma pessoa muito medrosa, e... a minha mãe também, a gente basicamente tem as mesmas características, são poucos características que eu peguei do meu pai. (SUJEITO JOÃO)

O recorte 2 apresenta a resposta de João quando o indagamos sobre quem da família ele era mais próximo, ele mencionou sua mãe. Há indícios de uma identificação com ela ao enunciar que ambos possuem personalidades muito parecidas, a gente é muito igual e destacou ter características parecidas com ela, no que diz respeito a ser medroso.

Vale ressaltar que João, por estar na condição de adolescência, pode estar em um momento de revivência do complexo de Édipo assim como nos ensinou Lacadée (2012). Em seu discurso podemos inferir que a mãe foi tomada como objeto de identificação $\underline{a}$ gente é muito igual, a gente... eu sou uma pessoa muito sensível a minha mãe também, e... a gente também é muito... como é que fala? A gente é muito medroso .

No decorrer dos recortes, apresentaremos outros trechos que nos indiciarão identificação com a mãe e conflito com a figura paterna. Vale retomar que Laplache e Pontalis (2004), valendo-se do pensamento freudiano, ressaltaram a identificação como a assimilação de aspecto, propriedade ou atributo do outro os transformando. Também vale lembrar que as identificações do complexo de Édipo dizem respeito as identificações simbólicas (LAPLANCHE; PONTALIS, 2004), nessa oportunidade de retomada João poderá reeleborar essas questões. 
Continuaremos nossa análise apresentando outro recorte em que aparece a relação de identificação com mãe:

\section{JOÃO: RECORTE 3}

Eu tenho... é... eu converso muito com a minha mãe, o meu pai as vezes não por que ele trabalha chega cansado tem que trancar a escola, só que eu converso muito com a minha mãe ela sempre me fala tipo o que ela pode falar para mim ela fala e eu falo o que eu posso falar para ela que é basicamente quase tudo, (SUJEITO JOÃO)

No recorte 3 João apresentamos o que o mobilizou frente a pergunta do por quê entende estabelecer relação de maior proximidade com sua mãe. Destacaremos inicialmente a seguinte sequência discursiva: me fala tipo o ela pode falar para mim ela fala e eu falo o que eu posso falar para ela que é basicamente quase tudo. Nesta sequência ele continua enunciar relação de proximidade com a mãe, trata-se de uma relação em que parece haver a cumplicidade das relações horizontais. Retomamos que Kehl (2000), a partir do pensamento lacaniano, nomeou essas relações como funções fraternas (KEHL, 2000), porém identificamos a marca do Outro quando há um limite no que pode ser dito, quando ele diz do quase tudo.

O quase tudo indicia a marca de uma barra, de um limite, apesar de uma aparente horizontalidade da relação. Trata-se de uma relação com a mãe marcada pela função paterna onde opera uma barreira.

Assim, compreendemos que as funções podem circular entre os membros da família e ser exercida mesmo com quem está em outros lugares, como o de mãe que ocorreu ainda com um limite que a coloca em lugar diferente de um semelhante. A relação fraterna também possibilita condições de identificação, mas imaginária, visto que remete à questão com o semelhante, com o espelho.

Portanto, a relação de identificação de João com sua mãe parece estar relacionada as questões da ordem simbólica, do Outro, bem como da ordem imaginária, do semelhante. 


\section{JOÃO: RECORTE 4}

meu pai é uma pessoa muito estressada, ele já chega do serviço um pouco cansado, aí se tipo eu parasse para conversar com ele assim ele ia.... ele é uma pessoa que se estressa muito fácil. E o meu pai ele é uma pessoa que gosta de tudo perfeito e eu não sou uma pessoa perfeita

... quando eu faço alguma coisa de errado ele já fica estressado e isso eu não gosto muito no meu pai mas fazer o que ele é meu pai e eu tenho que... (tom de voz abaixa) conviver com ele assim mesmo (SUJEITO JOÃO)

Apresentamos então, o recorte 4 que foi a resposta dada à pergunta sobre quem ele considerava uma pessoa menos próxima dele e então falou sobre sua figura paterna. Do recorte 4, iniciamos com a seguinte sequência discursiva: E o meu pai ele é uma pessoa que gosta de tudo perfeito e eu não sou uma pessoa perfeita. Nesta sequência, João parece estar em uma posição de não corresponder ao que interpreta o pai, seu Outro, esperar dele que é ser: uma pessoa perfeita.

O pai parece ocupar um lugar de pai imaginário, inquestionável, de modo que não consegue manter relação próxima com ele visto que pai é uma pessoa muito estressada. A interpretação dele de que o pai gosta de tudo perfeito parece indiciar que este pai esta num lugar de não barrado, um Outro sem furos, assim como diferenciou Soler (2016) e Laureano (2008). Porém, ao mesmo tempo ele parece justificar a posição do pai o interpretando como pessoa muito estressada, ou seja, marcado por uma castração.

João reagiu com alteração no tom da voz que abaixa, inferimos que isso o afeta, mas parece se resignar quando diz que ele é meu pai e eu tenho que... conviver com ele assim mesmo.

Portanto, o adolescente se queixa por não corresponder ao que o pai deseja, mesmo ele se identificando com a mãe, conflito fundamentado no complexo de édipo (NÁSIO, 2007). João também se identifica como castrado quando menciona que tem que conviver com ele assim mesmo.

Esta sequência discursiva nos dá indícios de que ao João foi transmitida a lei segundo a qual é necessário para viver em sociedade, entender que somos castrados e que podemos, a partir de nossas contingências, vivermos e extrairmos o que é possível para a nossa vida em civilização, assim como nos ensinou Freud (2010a). 
Seguiremos nossa análise com a apresentação do último recorte de João que apresenta sua posição frente a escola.

\section{JOÃO: RECORTE 5}

eu acho o estudo muito valioso principalmente para quem quer ser alguma coisa na vida por que tem gente que não ta nem ai, mas as pessoas que tem um objetivo... elas sempre pensam... nossa... se eu não fizer tal coisa hoje na escola talvez eu não alcance meus objetivos no futuro, e as pessoas que tem esse objetivo elas sempre procuram é... seguir as normas da escola ao pé da letra e não cometer nenhum deslize, para mim é para isso que ela serve, para orientar a gente para o nosso futuro. (SUJEITO JOÃO)

Ao dizer sobre a escola João se remeteu aos objetivos no futuro além de ser $\underline{\text { muito }}$ valioso principalmente para quem quer ser alguma coisa na vida. A escola parece ocupar um lugar utilitarista, não apresentou a relação que tem com a escola no agora. Desse modo, retomamos o teórico da educação Charlot (2014), quando destacou que o neoliberalismo tem influenciado a relação dos seres humanos com o saber de modo que este tem ocupado um lugar utilitarista se distanciando da função de prazer. No recorte 5, a escola não parece ocupar um lugar de sublimação onde a atividade intelectual teria função prazerosa, assim como nos ensinou o pensamento freudiano.

Além disso, a escola no discurso de João parece ter sido interpretada por ele como um lugar em que se deve seguir as normas da escola ao pé da letra e não cometer nenhum deslize. $\mathrm{O}$ erro, o furo, não parece encontrar lugar, assim como interpreta que seu pai espera dele: tudo perfeito. Assim, apesar de ter utilizado significantes diferentes, isso nos dá indício de que a relação do que pressupõe que as figuras verticais da escola esperam dele é o mesmo que ele interpreta que o pai espera dele.

Mesmo entendendo não poder cometer nenhum deslize, assim como o lugar que ele interpreta que o pai o coloca, notamos uma saída para angústia quando diz, no recorte 4: e eu não sou uma pessoa perfeita.

Assim, há um furo onde ele consegue lidar com a angústia e se constituir como sujeito, identifica saídas para a submissão ao discurso tudo perfeito que interpreta do pai e de não cometer nenhum deslize que entende vir da escola. 
João vive conflitos e consegue colocar em palavras às questões que envolvem diferenças nas relações familiares e nas diferentes gerações. Efetua autoquestionamentos e parece se identificaçar com a mãe e seu trabalho será de separação desses pais imaginários, assim como nos ensinou Alberti (2004)

Para ele, a escola está no lugar de seu pai no que diz respeito a rigidez na qual não se pode cometer nenhum deslize. Infere-se que a escola pode também ter uma função de ressignficação, assim como já há um processo na relação com o pai quando ele aponta que ele é uma pessoa que se estressa muito fácil.

A partir das análise dos cinco recortes do discurso de João, o que ele então nos ensina? Inicialmente vale lembrar que ele é de uma família de configuração nuclear, onde o pai trabalha e a mãe fica em casa. A relação mais próxima do que entendemos como fraterna ocorre com a mãe e não com o irmão. $O$ fato de viver com seus pais em uma família heterossexual, não o impediu de se identificar com a mãe. De modo que entendemos que não é a configuração familiar que vai determinar com quem os sujeitos de identificam, mas o trabalho do próprio sujeito frente a contigência de sua vida.

Vale a ressalva que podemos sim oferecer condições concretas as mais próximas do que entendemos serem de acordo com os direitos humanos, ou seja, nosso objetivo não é culpabilizar os sujeitos nem entendê-los como não determinados. Mas, apontamos que tem um trabalho dos sujeitos frente a isso.

O pai e a escola parecem ocupar o mesmo lugar para ele. Ele interpreta de um modo imaginário sendo que esperam dele perfeição e nenhum deslize. Mas, ele como sujeito consegue efetuar uma resposta em que ele entende não ser perfeito e, assim, podendo seguir seu caminho.

\subsection{Larissa}

Apresentamos nossa segunda participante que nomeamos como Larissa, na entrevista ela contava com treze anos e cursava o oitavo ano do ensino fundamental II. Larissa relatou que mora com sua mãe, três irmãos, "filha do padrasto" (sic), irmã e padrasto.

A vice-diretora da escola nos informou que ela tem um irmão envolvido na criminalidade, a mãe está sofrendo com câncer já em tratamento paliativo. O padrasto também está com câncer, mas não tão debilitado. 
No decorrer da entrevista, Larissa quase não falou sobre a situação de saúde da mãe e do padrasto, tampouco sobre a questão do irmão em conflito com e lei. Iniciaremos então as análises com o primeiro recorte de sua entrevista:

\section{LARISSA: RECORTE 1}

A minha irmã, a que tá no nono ano aqui, a gente é muito próxima, a gente só tem um ano de diferença então tudo o que sei ela sabe, a gente conversa... Sempre a gente conviveu junto, nunca... assim a gente briga mais daqui a pouco já tá se falando e a gente nasceu junto praticamente. (SUJEITO LARISSA)

Sobre o elemento de sua família que considera mais próxima a ela, Larissa falou sobre sua irmã relatando que a gente só tem um ano de diferença então tudo o que sei ela sabe, a gente conversa. Desta sequência discursiva ressaltamos a função do semelhante nos laços de família de Larissa, relação de cumplicidade e de horizontalidade, na quel tudo o que sei ela sabe. Isto nos remete a função fraterna do ensino de Kehl (2000), lembrando que a referida função está relacionada a uma identificação mental do sujeito com o pequeno semelhante, para além da relação com o espelho, tendo uma importante função na constituição do eu. Então, em seu discurso Larissa fala sobre sua identificação da ordem imaginária com a irmã.

$\mathrm{Na}$ relação imaginária com o espelho e com o semelhante, vale ressaltar Lacan (2008b) ao nos ensinar que também envolve a relação de rivalidade e que isso dependerá do momento do nascimento do irmão. No caso Larissa nasceu depois e próximo ao nascimento da irmã, há briga, mas também relação de cumplicidade.

Inferimos que houve um trabalho de Larissa em que ela utiliza da função fraterna aos moldes de uma suplência às outras funções para que se constitua, tendo em vista o silenciamento que efetuou de outros elementos da famílias, como a mãe.

Além disso, vale destacar que a irmã estuda na mesma escola, o que facilita a relação dela com a escola que pode ter um lugar de extensão à família.

Seguirmos então com a análise do discurso de Larissa. 


\section{LARISSA: RECORTE 2}

por que antigamente... é... que agora por exemplo eu tenho padrasto antigamente era só pai que podia, a mãe não podia divorciar e essas coisas e por que ah... ... as coisas são diferentes agora... eu não sei. (SUJEITO LARISSA)

O recorte 2 diz respeito ao que Larissa respondeu quando perguntamos sobre possíveis diferenças entre famílias atuais e de gerações anteriores. Ela destacou o aspecto do divórcio e que isso foi estendido às mulheres eu tenho padrasto antigamente era só pai que podia, a mãe não podia divorciar. Ela entendeu que esse divórcio podia ser feito pelo pai e não pela mãe.

Sabemos que, no Brasil, a lei do divórcio era, na letra da lei, igual para homem ou mulher (BRASIL, 1977), mas, ressaltamos os questionamentos do discurso feminista que revelou que, na prática, as mulheres sofriam desigualdade de direitos (LAGO, 2010)

Larissa identificou que houve direitos que foi estendido à mãe, o direito a uma escolha e uma satisfação. Esse aspecto de um novo lugar para a mulher foi apresentado no decorrer deste trabalho como um dos fatores que interferem nos novos arranjos familiares (ROUDINESCO, 2003) o que Larissa interpretou e enunciou em seu discurso como um novo lugar das mulheres na atualidade.

Seguimos então, sobre o que Larissa nos disse sobre a escola.

\section{LARISSA: RECORTE 3}

é onde eu encontro os meus amigos, posso me divertir, esquecer um pouco dos problemas que eu tenho em casa... as vezes, e... ah socializar com as pessoas é um lugar divertido também... é parte do meu futuro tipo, eu to aqui para poder construir um futuro melhor ... é... é isso. (SUJEITO LARISSA)

O recorte 3 apresenta o que Larissa falou quando indagamos sobre escola, destacamos que ela respondeu com entusiasmo por ela. Para além de uma relação utilitarista quando nos diz que eu to aqui para poder construir um futuro melhor, enfatizou o aspecto da socialização sendo que o significante divertir foi destacado.

A relação com os pares que a escola é onde eu encontro os meus amigos, remetenos também à função fraterna (KEHL, 2000) que para ela está articulada à diversão. A escola está associada a um lugar de esquecer um pouco dos problemas que eu tenho em 
casa de modo que parece ser uma maneira de lidar com as questões de risco e vulnerabilidade social de seu contexto.

Larissa nos ensinou sobre o aspecto do socializar na escola, lugar das identificações secundárias, assim como nos ensinado por Kehl (2000), essa socialização dita secundária pode ofertar contigências para encontrar saídas acerca das questões familiares de vulnerabilidade e, por que não, um lugar divertido?

Além disso, Larissa apresentou em seu discurso a operação da função fraterna sendo destacada frente ao silenciamento acerca dos lutos e questões sociais, relação em seu contexto familiar e escolar.

Prosseguiremos para a próxima análise.

\subsection{Joana}

Iniciaremos a análise de nossa terceira participante que nomeamos de Joana que estava com quatorze anos e cursava o oitavo ano do ensino fundamental no momento da entrevista. Ela residia com mãe, padrasto e duas irmãs.

Apresentaremos a seguir o primeiro recorte da entrevista.

\section{JOANA RECORTE 1}

Então eu não conhecia meu pai e nenhuma família do meu pai antes, ai depois de nove anos o meu pai apareceu ai agora só faz quatro ou cinco anos que eu conheço ele....

Ah por causa que tipo a minha mãe é separada do meu pai, e... as vezes por causa de pensão por causa dessas coisas acaba, tipo meu pai ele sai de um emprego ai ele não tem condição e ai minha mãe fica nervosa por que ela acha que ele não quer pagar mas ela fala que ele quer só que tipo... ele não tem condição e tal, ai sempre é isso e sempre tem confusão e tal. E também por causa que as vezes ah sei lá por causa que quando eles separam ai vão se distanciando (SUJEITO JOANA)

O recorte 1 apresenta parte da resposta de Joana quando nos disse o porque seu pai era o elemento da família que era mais distante, relatou que não conhecia o pai até seus nove anos. Joana interpretou que a separação conjugal dos pais e os conflitos judiciais da 
área de família foi o fator do distanciamento quando nos diz por causa que tipo a minha mãe é separada do meu pai, e... as vezes por causa de pensão.

Retomamos a adolescência como um trabalho de separação e reelaborações (ALBERTI, 2004) e vale referenciar o texto de Freud (2015) O romance familiar dos neuróticos que nos ensinou sobre o nomeado romance familiar, este diz respeito a devaneios elaborados pela criança sobre os pais de modo a exaltá-los, mesmo quando fantasiam que tem outros pais, ainda é uma forma de exaltá-los. O pai de Joana, que esteve ausente até os nove anos dela, foi fantasiado de modo a a ser impotente, desprovido, e que por iss não pode ajudar no sustento da filha.

Portanto, para além da questão concreta envolvendo o direito de família posta no conflito, notamos a defesa do pai e aliança junto a ele frente ao conflito “... ele não tem condição e tal" e que essa defesa podemos interpretar como um investimento amoroso.

Não sabemos como se articulou simbolicamente a relação de Joana com seu pai, quando vivinciou o complexo de Édipo na infância, mas vale destacar que no momento da entrevista havia um investimento amoroso ao pai, sendo a mãe um obstáculo que acha que ele não quer pagar mas... ele não tem condição e tal. Tal configuração nos remete ao conflito edipiano (NÁSIO, 2007).

No discurso de Joana ela parece falar sobre seu conflito edípico, mesmo que o pai esteve ausente por muitos anos da vida dela.

Seguiremos então com nossa análise.

\section{JOANA RECORTE 2}

Ah é tudo por eles que quer seu bem eles que vão sempre tá ali do seu lado e te apoiando, te dando bronca, falando o que é certo e o que é errado, são eles que vão sempre tá ali.... as famílias do passado eram mais rígidas assim, agora tem pais que não ta nem ai para os filhos deixa fazer o que quer, e por causa disso muitas pessoas acha que o pai na liga ou se não deixa, mas vezes é... por sei lá... tem algum problemas ou necessidade alguma coisa assim, e ai muitas vezes acaba a família por causa de motivos bobos (SUJEITO JOANA).

O recorte 2 do discurso de Joana foi a resposta dela frente à pergunta sobre o que era família para ela e as diferenças entre as famílias de atuais e de gerações anteriores. Destacamos a sequência discursiva que vão sempre tá ali do seu lado e te apoiando, te 
dando bronca, falando o que é certo e o que é errado, são eles que vão sempre tá ali.... em que a expressão sempre tá ali se repetiu, e inferimos o lugar do supereu, constitutivo do ser humano.

Comparando as gerações, ressaltou que as famílias do passado eram mais rígidas assim, agora tem pais que não ta nem ai para os filhos deixa fazer o que quer nos remetendo novamente ao aspecto da permissividade na atualidade, assim como foi pensando por Soler (2016).

Articulada a essa sequência discursiva inferimos que ela diz de si e de seus conflitos familiares quando diz que muitas pessoas acha que o pai na liga ou se não deixa, mas vezes é... por sei lá... tem algum problemas ou necessidade. Inferimos que_essa é a história que Joana elaborou frente ao conflito judicial e, assim, justifica para a ausência concreta dele, interpretamos que essa posição está relacionada ao conflito edípico inconsciente, em que o pai está sendo tomado como objeto de investimento amoroso (NÁSIO, 2007).

Prosseguimos, então, para análise do próximo recorte do discurso de Joana.

\section{JOANA RECORTE 3}

tem vezes que eu saio mais com as primas do que com a minha mãe por que ela trabalha $e$ não tem tempo... Ah por causa que a gente conversa mais, a gente convive junto, a gente passa mais tempo, a gente conversa e essas coisas (SUJEITO JOANA)

O recorte 3 corresponde à resposta de Joana sobre com quem ela considera conviver melhor e destacamos a a sequência discursiva eu saio mais com as primas do que com a minha mãe por que ela trabalha e não tem tempo... Ah por causa que a gente conversa mais, a gente convive junto, a gente passa mais tempo. Vale ressaltar a repetição do significante tempo articulado como dificultador da convivência com a mãe ela trabalha e não tem tempo assim como um facilitador a gente passa mais tempo.

Interpretamos que para o tempo ao qual ela se remete não corresponde ao tempo cronológico. No texto $O$ tempo lógico e a asserção da certeza antecipada: um novo sofisma (LACAN, 1998b) nos remeteu ao sofisma para compreender o tempo lógico e nos apresentou três momentos de evidência "o instante do olhar, o tempo para compreender e o momento de concluir" (LACAN, 1998b, p. 204). 
O instante do olhar é uma instância do tempo que abre o intervalo para um movimento lógico de formulação do problema e o tempo para compreender emerge uma intuição que exige um "tempo de meditação" (LACAN, 1998b, p. 205). Já o momento de concluir corresponde a um "movimento lógico na decisão de um juízo" (LACAN, 1998b, p. 206). Destacando que essa conclusão se trata de um ato, visto que "todo juízo é essencialmente um ato" (LACAN, 1998b, p. 208).

Desse modo, Lacan (1998b) desloca o tempo de seu aspecto cronológico espacial para o tempo subjetivo e lógico, para algo que é um ato do próprio sujeito, é o próprio sujeito.

Então, entendemos o tempo no dizer de Joana como um movimento de aproximação ou de distanciamento da mãe articulado ao significante trabalho - por que ela trabalha e não tem tempo - que interdita a relação com a mãe. Já a gente passa mais tempo é o movimento de aproximação.

Assim sendo, apresentaremos a seguir a análise do último recorte do discurso de Joana.

\section{JOANA RECORTE 4}

Então escola é um lugar... eu vou falar a verdade eu não gosto de estudar mas tem que estudar né, o que adianta você chegar lá na frente sem saber nada, as vezes você nem consegue ir pra frente, você nem consegue arrumar um trabalho bom, se você não arrumar trabalho você não vai arrumar alguém e ai se você quiser ter uma família, você não vai ter como sustentar sua família e nem como dar o melhor para ela, eu acho que isso atrapalha muito também (SUJEITO JOANA)

Eis o discurso de Joana frente ao signficante escola, inicialmente destacamos a seguinte sequência discursiva, eu vou falar a verdade eu não gosto de estudar mas... o que adianta você chegar lá na frente sem saber nada, as vezes você nem consegue ir pra frente, você nem consegue arrumar um trabalho bom. Aqui nos remetemos ao lugar utilitarista da escola em nosso contexto neoliberal, assim como pensou Charlot (2014).

Vale ressaltar a articulação do trabalho com o oportuniza a família se você não arrumar trabalho você não vai arrumar alguém e ai se você quiser ter uma família, você não vai ter como sustentar sua família e nem como dar o melhor para ela. 
O significante trabalho apareceu ao mencionar a mãe no recorte 3 , já o pai é desprovido de trabalho, interessante notar que frente ao pai Joana utiliza o significante emprego (Recorte 1). Podemos inferir que o trabalho é o siginificante o qual o pai é desprovido.

Desse modo, no discurso de Joana escutamos que as questões do conflito edípico estão subjacentes aos conflitos familiares envolvendo dever de sustento (pensão) e parece que há um investimento amoroso ao pai, mesmo que este esteve ausente até os nove anos dela. A escola ocupou uma função de propiciar que ela forme sua própria família lá na frente.

\subsection{Adriano}

Apresenteremos nosso último participante a quem nomeamos como Adriano, no momento da entrevista ele estava com quatorze anos e cursava o nono ano, informou que morava com a mãe e dois irmãos. Além disso, ele trabalha como jovem aprendiz e ressaltou que guardava dinheiro para sair de casa, assim que completar dezoito anos.

Então, seguiremos com as análises da entrevista realizada.

\section{ADRIANO RECORTE 1}

Muita pouca gente assim, família mesmo não é algo que você pode falar que é só de sangue para mim... é alguém que você pode realmente contar, tem muita pouca gente. Minha mãe eu nem sei se eu considero ela mesmo da família por que muito problema que eu já passei com ela, e... é tanta briga todo dia, eu mesmo tava pensando em morar com meu pai passar a guarda pra ele mas nem com meu pai ta dando pra morar... Por que também ele é usuário e minha mãe é alcoólatra (SUJEITO ADRIANO)

O recorte 1 apresenta a resposta de Adriano quando questionado sobre o que é família. Ressalta-se a sequência discursiva não é algo que você pode falar que é só de sangue para mim... é alguém que você pode realmente contar. Ressalta-se o significante contar, trata-se de contar algo para alguém? Contar com alguém?

Retomamos que o trabalho da adolescência diz respeito a separação da autoridade paterna, dos pais imaginariamente idelizados (ALBERTI, 2004), para haver uma separação é necessário que primeiro tenha havido uma alienação (VOLTOLINI, 2011). 
As figuras parentais com quem Adriano provavelmente se alienou correspondem ao pai usuário e mãe é alcoólatra, estes contados por Adriano como sujeitos que apresentam modo de gozo em que a substância psicoativa entra em um lugar de completude imaginária, tão próprio de muitos sujeitos na conteporaneidade (BRIOLE, 1994), própria do discurso do capitalista (HORNE, 2007).

O modo de gozo dos pais parece ter esvaziado suas funções parentais de modo a Adriano se localizar em um desamparo visto que tava pensando em morar com meu pai passar a guarda pra ele mas nem com meu pai ta dando pra morar.

Então, Adriano frente ao significante família apresenta suas queixas em relação ao ela e afirma que não se trata de só de sangue e sim de alguém que você pode realmente contar.

Seguiremos então para o próximo recorte.

\section{ADRIANO RECORTE 2}

Ah, é bem monótona, assim... sabe? Eles não se falam muito... não quer saber um do outro, mas quando vai tipo.. em relação a mim e ao K... que são meu irmãos "Ai.. seu pai tem que fazer isso... aquilo... porque ele também é responsável por vocês.. " Ah... mas nenhum deles assume realmente a responsabilidade... Ninguém... assim... qué assumir de verdade... a guarda tá com minha mãe, ela fala que assume, mas num assume... não porque se ela quisesse mesmo ela parava de beber... de fumar... de fazer tudo isso. Ela não para... então pra ela tá foda-se. (SUJEITO ADRIANO)

O recorte 2 apresenta parte da resposta de Adriano quando indagamos se eles costumavam fazer algo em família, destacamos a sequência discursiva Ninguém... assim.... qué assumir de verdade... a guarda tá com minha mãe, ela fala que assume, mas num assume não porque se ela quisesse mesmo ela parava de beber.. de fumar... de fazer tudo isso, nesta Adriano nos conta sobre os esvaziamento dos pais em relação ao investimento aos filhos. Trata-se de um modo de gozo em que a substância psicoativa é colocada em lugar de objeto que imaginariamente tampona a falta, de modo a não fazer laço e tão próprio ao discurso do capitalista (HORNE, 2007)

A questão legal é posta ao mencionar que a guarda tá com minha mãe, esse signficante do universo do direito de família esteve presente no discurso, porém, não garante que ela assume realmente a responsabilidade. $\mathrm{O}$ adolescente também nos conta 
que sua mãe se queixa para ele de que o pai "Ai.. seu pai tem que fazer isso... aquilo... porque ele também é responsável por vocês", mas, na posição de questionamento (ALBERTI, 2004) Adriano questiona a queixa da mãe ao afirmar que ela também não se responsabiliza, sendo que Ninguém... assim... qué assumir de verdade.

Ao questionar o mãe, inferimos que Adriano também está questionando o Outro que agora se mostra furado.

Proseguimos então para nosso próximo recorte.

\section{ADRIANO RECORTE 3}

Teve até uma vez que minha mãe tava grávida e aí rolou a briga... aí eu tive que me esconder no quarto do meu irmão... aí o maior motivo pra eu morar aqui no Ipiranga, eu morava na Camilo de Matos... foi porque meu pai usou droga... minha mãe brigou, né? Minha mãe traiu ele... meu pai ficou bravo e incendiou a casa... aí... não tinha como a gente morar lá... a gente se mudou pra cá. (SUJEITO ADRIANO)

O recorte 3 apresenta uma cena que Adriano contou sobre a briga, vale ressaltar o artigo definido que nos faz inferir que não se trata de uma briga qualquer, mas a briga que nos faz pensar em uma cena que traz marcas para ele. Ressaltamos a sequência discursiva Minha mãe traiu ele... meu pai ficou bravo e incendiou a casa. Nesta sequência discursiva, inferimos que o pai, submetido ao discurso do capitalista (LACAN, 2005a), tendo em vista sua posição subjetiva que o álcool está em um objeto de suposta completudo, efetua um ato frente ao conflito envolvendo a traição, a palavra não faz circular frente ao conflito conjugal posto.

Na sequência discursiva aí eu tive que me esconder no quarto do meu irmão... Adriano nos conta que foi exposto a um risco sério risco de violação de sua integridade física, bem como de todos da família e diz como conseguiu lidar com a situação. Ressaltase que colocar em palavras a cena, pode ser um modo de ventilação dos afetos (DOLTO, $2011)$.

Rosa (2009) nos ensinou que para além de uma ventilação de afetos, colocar em palavras pode ofertar possibilidades para uma ressignificação, desde que haja uma implicação no que está se dizendo, ou seja, que vá além de uma queixa. A autora destacou que e os não-ditos podem operar como mandatos, são apreendidos como estereótipos que 
ocupam o lugar da simbolização, no recorte 3 Adriano colocou em palavras o modo de seus pais se relacionarem e de lidarem frente com os conflitos conjugais.

Ao contar a cena, há a chance de Adriano simbolizar essa violência vivida e não repetir as modos violentos de se relacionar e, caso ele deseje ocupar o lugar de pai e de parceiro sexual, não efetue essa trasmissão como um imperativo.

Vamos, então, para nosso próximo recorte.

\section{ADRIANO RECORTE 4}

Eu não tenho um conceito assim... de família, só acho que família, pra mim, é alguém que eu possa contar mesmo... Alguém que pode me ajudar, de verdade, que eu possa... sempre pedir uma força, assim, sabe? Não precisa ser de sangue... assim... o meu amigo... pra mim ele é família... ele é meu irmão... (suspiro)... então... é alguém que você vai... realmente poder contar (SUJEITO ADRIANO)

Quando indagamos o que é família para Adriano ele a resposta foi o que apresentamos no recorte 4, para ele família não corresponde a um saber referencial, ou seja, a um conceito. Família é alguém que eu possa contar mesmo... Alguém que pode me ajudar, de verdade, que eu possa... sempre pedir uma força, assim, sabe? A sequência discursiva apresenta o significante contar novamente e articulado ao ajudar e pedir uma força, trata-se de uma posição de amparo.

Na sequência discursiva Não precisa ser de sangue... assim... o meu amigo... pra mim ele é família... ele é meu irmão... (suspiro)... então... é alguém que você vai... realmente poder contar ele ressalta que a família não correponde necessariamente as relações biológicas, assim como nos ensina Lacan (2008b). A família é aquele com quem é pode contar e no caso corresponde a seu amigo o suspiro demonstra a relação afetiva posta nesse dizer.

A função fraterna (KEHL, 2000) para Adriano ocupa o lugar de acolhimento frente ao desamparo que apresenta em relação ao esvaziamento de cuidados e proteção de seus pais, o que tão bem nos ilustrou com o suspiro aliviado quando mencionou o amigo.

Vale destacar que a função fraterna não diz respeito necessariamente aos laços consanguíneos (KEHL, 2000) - Não precisa ser de sangue - e sim um par que estabelece uma relação horizontal e apoio na transgressão. No caso de Adriano, a transgressão é de um imperativo de gozo na violência e no abuso de substância psicoativas, vale citar Freud 
quando nos ensinou que "De fato, o progresso da sociedade baseia-se nessa oposição entre as duas gerações" (FREUD, 2015, p.192).

Seguiremos para nosso próximo quinto e último recorte da entrevista de Adriano.

\section{ADRIANO RECORTE 5}

Escola... Meu... escola pra mim é um lugar... também... tanto pra estudar, um lugar de aprendizado, como um refúgio, da minha casa... assim, sabe? Do meu pai... da minha mãe... dos meus irmãos. É um lugar onde eu posso passar com amigos e me diverti também... Tanto como aprender o que é essencial , tanto quanto eu posso sai... assim... de perto da minha mãe e desse problemas. (SUJEITO ADRIANO)

O recorte 5 nos apresenta o que Adriano diz frente ao signficante escola, destacamos a seguinte sequência discursiva escola_pra mim é um lugar... também... tanto pra estudar, um lugar de aprendizado, como um refúgio, da minha casa... assim, sabe? Diferente dos outros participantes, Adriano diz do aspecto sublimatório da atividade intelectual da escola (FREUD, 2017a) quando menciona o lugar de aprendizado que está articulado ao agora e não ao futuro.

Para além da atividade intelectual, Adriano, em seu discurso, ressaltou o aspecto do refúgio, na sequência discursiva É um lugar onde eu posso passar com amigos e me diverti é ressaltado o lugar das relações que a escola propicia, relações com os pares que promove diversão.

Sendo assim, destacamos que Adriano apresenta posição subjetiva de questionamento dos pais, planeja possibilidades diferentes para si, responsabilizando-se frente a seu desejo e buscado saídas diferentes de seus pais para lidar com o mal-estar. A escola ocupou lugar de refúgio propiciando relações fraternas.

Quinet (2009) discorreu sobre um dos lugares que a escola psicanalítica pode vir a ocupar aos analistas que é de "refúgio contra o mal estar na civilização" (QUINET, 2009, p.11). Lugar esse onde não se espera imperar o discurso do mestre, devendo ser sustentada pelo avesso deste discurso, o do analista.

Já na educação escolar cotidiana é presente a lógica do homogeneização, porém, retomamos a necessidade de encontrarmos um ponto de equilíbrio entre o universalismo e 
o particular nos planejamentos da educação escolar, assim como propôs Charlot (2014) e Freud (2010b) em seu texto Considerações atuais sobre guerra e morte.

Adriano localizou na escola este espaço de refúgio às relações de violência vivida em sua família, a escola ofertou contingência de ele encontrar na relação horizontal possibilidades de espaço de escuta.

Finalizamos nossa apresentação dos discursos dos adolescentes, prosseguiremos para nossas considerações finais de modo nas quais articularemos nossos resultados com a literatura e com nossas reflexões. 


\section{CONSIDERAÇÕES FINAIS}

Antes de prosseguirmos, vale ressaltar que o presente capítulo não corresponde a um esgotamento da questão, mas, buscamos articular o que nossas análises nos fizeram pensar a respeito da família e escola a partir do discurso dos participantes e nossos objetivos que foram de analisar o que os participantes falaram a partir do significante família de modo a localizar os lugares que os adolescentes colocam a família e escola no que diz respeito a endereçamentos e transmissão da cultura.

Destaca-se que a partir da literatura psicanálitica pesquisada para o presente trabalho a família corresponde a uma relação entre um adulto e um tutelado, foi entendida como um lugar de transmissão. Portanto, não se trata de um grupo qualquer, mas de um local onde se pressupõe que um sujeito integre outro em uma cultura, assim como ocorre na escola.

Vale destacar a referência a Ramon e col (2016) ao enfatizaram que, no pensamento lacaniano, a subjetividade tem a ver com sua época. Portanto, quando destacamos os aspectos da particularidade, aspecto este enfatizado acerca dos participantes, não estamos excluindo as incidências do social.

Então, retomando que a família é o lugar de assujeitamento primordial a uma lei simbólica que instaura a cultura, indagamo-nos: a horizontalidade das relações familiares na contemporaneidade, assim como defende Roudinesco (2003), além da permissividade na sociedade como nos ensinou Soler (2016), impede a continuidade da civilização a ponto de vivermos em um estado de caos?

No caso dos adolescente escutados entendemos que não porque o assujeitamento a uma ordem apareceu nos discursos dos adolescentes escutados. Eles não estão em uma situação de errância como foi descrito por Castilho (2017), estão ancorados em um discurso do Outro, apesar de imersos em uma cultura onde prevalece o discurso do capitalismo que tem como característica ser um "pseudodiscurso" (HORNE , 2007, p. 62) porque não faz laço.

Apesar das particularidades, identificamos que na interpretação dos adolescentes escutados, família é o que nos dá uma referência que podemos ou não utilizar, família também é aquela que escolhemos no decorrer de nossa vida que nos ampara e nos ajuda a ressignificar nossas referências. 
Ao pensar nas famílias em rede como mencionado por Roudinesco (2003), entendemos se tratar de uma prevalência de relações horizontais, que foram escutadas quando os adolescentes falavam sobre os pares, mas também presentes nas relações verticais. São outros modos de se relacionar em que se pode dizer "quase tudo" (JOÃO: RECORTE 3) ao adulto, ou seja, houve uma interdição presente apesar do predomínio da horizontalidade.

Retomando Elia (2010) ao destacar que sujeito é um ato, entendemos que frente as contigências, os sujeitos podem se constituir a partir de uma resposta frente ao Outro. Assim, os adolescentes escutados nos ensinou que as subjetivações não são determinadas a algum tipo de arranjo familiar específico, e sim em como eles se posicionaram frente às contingências de suas famílias, a partir do que foi transmitido para eles.

Isso não quer dizer que não deve haver incentivos e políticas públicas voltadas para as famílias e que o sofrimento familiar seja irrelevante na constituição dos sujeitos, Soler (2016) nos ensinou que o processo de identificação com os sofrimentos dos pais ocupa um importante lugar na transmissão da história coletiva dos homens, há uma transferência da dor entre gerações.

Mas o que queremos ressaltar é o aspecto do vir a ser, ao não partirmos de um pensamento determinista sobre as famílias podemos legitimar suas potencialidades. Pensamos que as famílias devem ser escutadas e alvo de políticas públicas, mas de modo a ofertar aberturas nos dicursos e não partirmos de posições que favorecem cristalizações discursivas. Assim, entendemos que seja favorável para os sujeitos emergirem.

Desse modo, defendemos que trabalho da adolescência de questionamento do Outro é particular, não havendo uma determinação do sujeito em relação às suas configurações familiares.

Apesar das particularidade, há incidências das questões da época em seus discursos, uma delas foi a diferença do lugar da mulher na sociedade no sentido de acesso a mais direitos. Assim, o discurso feminista tem se reverberado e entendido como uma marca diferencial entre as gerações.

Outra questão e sobre uma maior permissividade, João nos ensinou que os assujeitamentos a uma lei, a do assujeitamento ao Outro que instaura a civilização, parece estar inscrito em seu discurso, mas de modo diverso comparado às duas gerações à sua, que eram mais marcadamente atravessadas pelo discurso autoritário patriarcal do que sua geração. 
Para além de atingir os objetivos, a pesquisa propiciou a escuta dos adolescentes que estão em momento de questionamento do Outro e assim poder localizar seus furos. Adriano nos ensinou que apesar de ter vindo de um grupo familiar violento, que ele apresenta relação ambigua, ele pôde se consituir como sujeito e se posicionar de modo a romper, até o momento, com um destino de violência.

$\mathrm{O}$ furo de Adriano foi a possibilidade que ele teve de contar (ADRIANO RECORTE 1) e com pessoas que fizeram as vezes do que ele entendeu por família, já João teve o furo da relação mais próximo de algo horizontal que estabeleceu com sua mãe e assim pôde colocar em palavras suas angústias frente a relação com o pai.

Joana se remeteu ao romance familiar para lidar com a ausência paterna, bem com uma identificação com a mãe. E Larissa, buscou na função fraterna, enfrentamento para as dificuldades.

Quanto ao significante escola, ela foi articulada às relações fraternas que podem inclusive ofertar refúgio (ADRIANO RECORTE 5) e lugar para se divertir (LARISSA RECORTE 3). Interpretamos que nos discursos dos participantes, a escola ocupou um lugar de referência para as identificações imaginárias e lugar de amenizar as angústias.

Faz-se imprescindível destacar que no cotidiano de trabalho em centro de saúde mental infanto-juvenil, escuta-se uma relação de intenso sofrimento com a escola que contrasta com a relação que escutamos nesta pesquisa.

Assim, registramos o seguinte questionamento: os educadores pressupõem que a escola possa ocupar lugar que vá além da atividade intelectual? Ou seja, que a escola ocupe um lugar de transmissão para além de um espaço de ensino, assim como diferenciou Voltolini (2011)? Caberia uma pesquisa.

Faz-se imprescindível ressaltar que, exceto no discurso de Adriano, a escola não ocupou um lugar de atividade intelectual, de sublimação. Sendo assim, no que diz respeito a um espaço de saber referencial, a escola ocupou lugar utilitarista, assim como Charlot (2014) referiu estar o lugar da atividade intelectual na atualidade.

Também podemos pensar o lugar da atividade intelectual a partir dos efeitos do discurso do capitalista, assim como comentado por Horne (2007), na qual o objeto não é causa do desejo, mas um excesso que imaginariamente tenta tamponar a falta constituinte. Desse modo, a atividade intelectual apareceu como objeto necessário a uma possível completude no futuro, mas não como uma atividade prazerora, sublimatória.

Vale lembrar que, na escola onde nossos participantes estudavam e onde as entrevistas foram realizadas, nós identificamos que os sinais de entrada e saída das aulas 
eram músicas, escolhidas pelos alunos e que variam semanalmente. Pereira (2005) destacou a necessidade de abertura nos discursos na escola, sem perder as funções de mestre, mas permitindo uma circulação de modo a não se cristalizarem discursos.

Inferimos que a escola foi um lugar em que os pedidos dos alunos são parcialmente acolhidos, assim, infere-se que corresponda a um lugar em que os discursos possam circular e, assim, oferecer condições para que os sujeitos apareçam.

Sendo assim, finalizamos defendendo que a a psicanálise é uma ética, a qual considera nossos furos constituintes de modo a oferecer abertura para subversão do impactos do neoliberalismo na relação com o saber (referencial), visto que pressupomos que há um sujeito do inconsciente que ali se impõe a revelia de métodos pedagógicos e de arranjos familiares. O que nos resta é escutar e considerar seus questionamentos. 


\section{REFERÊNCIAS BIBLIOGRÁFICAS}

AGAMBEN, Giorgio. O que é contemporâneo? In: O que é contemporâneo e outros ensaios. (HONESKO, Vinícius Nicastro, trad). Chapecó: Argos, 2009.

ALBERTI, Sônia. O adolescente e o Outro. Rio de Janeiro: Zahar, 2004 ARIÈS, Philippe. História social da criança e da família. (FLAKSMAN, Dora, trad). 2 ed. Rio de Janeiro: LTC, 2012 (Trabalho original publicado em 1973)

ASSOLINI, Filomena Elaine Paiva; DORNELAS, Camila Carrari. Práticas de reescrita: possibilidades de instauração da autoria. Revista do Programa de Pós-graduação em Letras da Universidade de Passo Fundo- v12-n.1- p. 113-136- jan./jun., 2016 Disponível em https://bit.ly/2NpsDIm Acesso em 18.Setembro.2018

ASSOLINI, Filomena Elaine Paiva. Interpretação e letramento: os pilares de sustentação da autoria. 269 p. Tese (Doutorado em Ciências, Psicologia) Universidade de São Paulo, Ribeirão Preto, 2003.

BACKES, Carmen. O fóbico e seu acompanhante. In: (org). A clínica psicanalítica na contemporaneidade. Porto Alegre: Editora da UFRGS, 2007, ISBN 978 85-386-0387-0. Disponível em http://books.scielo.org/id/ckhzg/epub/costa9788538603870.epub Acesso em 17. Jul. 2019

BAIRRÃO, José Francisco Miguel Henriques. Adolescência em transe. In: TFOUNI, Leda Veridiana (Org). Letramento, Escrita e Leitura. Campinas, Mercado de Letras, 2011 - A imaginação do Outro: Intersecções entre psicanálise e hierologia. Paidéia, 11 (20), 11-26, 2001. Disponível em https://www.revistas.usp.br/paideia/article/view/6097 . Acesso em: 16. Maio. 2019.

BERNARDINO, Leda Mariza Fischer; KUPFER, Maria Cristina Machado. A Criança como mestre do gozo atual: desdobramentos da "pesquisa de indicadores clínicos de risco para o desenvolvimento infantil”. Rev. Mal- Estar Subj., Fortaleza, v. 8, n. 3, set., 2008 Disponível em https://bit.ly/2MimjBi Acesso em 12.Agosto. 2018

BARTIJOTTO, Juliana. O discurso sobre o ato infracional materializado no Estatuto da Criança e do Adolescente. 150 p. Dissertação (Mestrado em Psicologia) Universidade de São Paulo, Ribeirão Preto, 2014 
BLEGER, José. A entrevista psicológica: seu emprego no diagnóstico e na investigação. In: Temas de psicologia: entrevista e grupos. São Paulo: Martins Fontes, 1980 (Trabalho original publicado em 1979).

BRASIL. Lei número 6.515, de 26 de dezembro de 1977. Regula os casos de dissolução da sociedade conjugal e do casamento, seus efeitos e seus respectivos processos, e dá outras providências. Disponível em http://www.planalto.gov.br/ccivil 03/LEIS/L6515.htm Acesso em 24. Agosto. 2019

BRIOLE, Guy. A adolescência e adolescente: o impossível do desejo (LEMOS, Márcia Carvalho; MELLO, Eucy trad). Agente: revista de Psicanálise/ Escola Brasileira de Psicanálise/Seção Bahia. -a.1, n.1 (jun./1994)-.-Salvador: EBP/BA, pp. 9-26, 1994.

CASTILHO, Pedro Teixeira. Os nomes do laço social das adolescências na contemporaneidade: errância, sintoma e corpo. In: PEREIRA, Marcelo Ricardo (Org). Os sintomas na educação hoje: o que fazemos com isso? Belo Horizonte: Scriptum, 2017.

CÊRA, Flávia. Como se (dá) conta (d)o não-dito? Nova Rede Cereda Brasil, Folha dos Núcleos. Número 40, 2017, pp. 44-45

CHARLOT, Bernard. Da relação com o saber às práticas educativas (livro eletrônico). São Paulo: Cortez, 2014

CHAUÍ, Marilena. A política contra a servidão voluntária. In: Convite à

Filosofia. 14a ed. São Paulo: Editora Àtica, 2015

COHEN, Ruth Helena P. O traumático encontro com os outros da educação: a família, a escola e o Estado. Psicologia em Revista, Belo Horizonte, v. 10, n.16, p. 256- 269, 2004. Disponível em https://bit.ly/2KKaS0c Acesso em 10.Agosto. 2018

COSSI, Rafael Kalaf; DUNKER, Christian Ingo Lenz. A diferença sexual de Butler a Lacan: gênero, espécie e família. Psicologia Teoria e Pesquisa, Vol 33, p. 1-8, 2017. Disponível em https://bit.ly/2yw2yx5 Acesso em 11. Outubro. 2018

COUTINHO, Luciana Gageiro. Adolescência, Cultura Contemporânea e Educação. Estilos da Clínica, Vol. XIV, n² 27, 134-149, 2009 Disponível em https://bit.ly/2vzybFv Acesso em 10.Agosto. 2018

DOLTO, Françoise. Quando os pais se separam - (RIBEIRO, Vera, trad). 2a ed. Rio de Janeito: Zahar, 2011 (Trabalho originalmente publicado em 1988)

A imagem inconsciente do corpo. (MORITZ, N. ; LEVY, M., trad).

2a ed. São Paulo: Perspectiva, 2010 (Trabalho originalmente publicado em 1984) 
DOR, Joel. Introdução à leitura de Lacan: o inconsciente estruturado como uma linguagem. (REIS, C.A, trad). Porto Alegre: Artes Médicas, 1989.

DUNKER, Christian Ingo Lenz; PAULON, Clarice Pimentel; MILÁN-RAMOS, J. Guilhermo. Análise Psicanalítica de Discursos: Perspectivas Lacanianas. 2 ed. São Paulo: Estação das Letras e Cores, 2017.

ELIA, Luciano. O conceito de sujeito. 3 ed. Rio de Janeiro: Jorge Zahar ed, 2010.

FREUD, Sigmund. Três ensaios sobre a teoria da sexualidade. In:

Obras completas volume 6. (SOUZA, Paulo César, trad). São Paulo: Companhia das letras, 2017a (Trabalho originalmente publicado em 1905) Inibição, sintoma e angústia. In: Obras completas volume 17. (SOUZA, Paulo César, trad). São Paulo: Companhia das letras, 2017b (Trabalho originalmente publicado em 1926)

O romance familiar dos neuróticos. In: Obras completas volume 8. (SOUZA, Paulo César, trad). São Paulo: Companhia das letras, 2015 (Trabalho originalmente publicado em 1909)

.Cinco Lições de Psicanálise cinco lições de psicanálise. In: .Obras completas volume 9. (SOUZA, Paulo César, trad). São Paulo: Companhia das letras, 2013 (Trabalho originalmente publicado em 1910) .Mal-estar na civilização. In: .Obras completas volume 18. (SOUZA, Paulo César, trad). São Paulo: Companhia das letras, 2010a (Trabalho originalmente publicado em 1930)

.Considerações atuais sobre guerra e morte. In:

Obras completas volume 12. (SOUZA, Paulo César, trad). São Paulo: Companhia das letras, 2010b (Trabalho originalmente publicado em 1915)

- Estudos sobre histeria. In: Obras completas volume 2. (OITICICA, Cristiano Monteiro; Ribeiro, Vera, trad). Rio de Janeiro: Imago, 2006a. (Trabalho originalmente publicado em 1969)

- Prefácio a Juventude Desorientada, de Aichhorn. In: . Obras completas volume 19. (SOUZA, Eudoro Augusto Macieira de, trad). Rio de Janeiro: Imago, 2006b. (Trabalho originalmente publicado em 1925)

Algumas reflexões sobre a psicologia do escolar. In: . Obras completas volume 13. (MUNIZ, Órizon Carneiro, trad). Rio de Janeiro: Imago, 2006c. (Trabalho originalmente publicado em 1914) 
- Recomendações aos médicos que exercem a psicanálise. In: Obras completas volume 12. (ABREU, José Octávio de Aguiar, trad).

Rio de Janeiro: Imago, 2006d) (Trabalho originalmente publicado em 1924)

GINZBURG, Carlo. Sinais: raízes de um paradigma indiciário: In: GINZBURG, Carlo. Mitos, emblemas e sinais (CAROTTI, Federico, trad). 2 ed. São Paulo: Companhia das letras, 2016 (Trabalho originalmente publicado em 1986).

GOHN, Maria da Glória. Manifestações e protestos no Brasil: correntes e contracorrentes na atualidade. São Paulo: Cortez editora, 2017.

GOLDANI, Ana Maria. Família, gênero e políticas: famílias brasileiras nos anos 90 e seus desafios como fator de proteção. Revista Brasileira de Estudos de População, V.19, n.1, jan./jun., 2002 Disponível em https://bit.ly/2MFtEYI Acesso em 10.Agosto. 2018 HORNE, Bernardino. Os nomes do amor. Opção lacaniana, (48). Março/2007 KEHL, Maria Rita. Lugares do feminino e do masculino na família. in: COMPARATO, Maria Cecília; MONTEIRO, Denise (orgs). A criança na contemporaneidade e a psicanálise. Família e Sociedade: Diálogos interdisciplinares. Vol 1. São Paulo: Casa do Psicólogo, 2001

Existe uma função fraterna? In: (Org). Função

fraterna. Rio de Janeiro: Relume Dumará, 2000. pp.

LACAN, Jacques. Estou falando com as paredes: conversas na Caplea de Sainte-Anne. (RIBEIRO, Vera, trad). Rio de Janeiro: Jorge Zahar, 2011 (Trabalho original publicado em 2011)

- Seminário, livro 11: os quatro conceitos fundamentais da psicanálise. (MAGNO, M.D, trad) 2a ed. Rio de Janeiro: Jorge Zahar, 2008a (Trabalho original publicado em 1964)

Complexos familiares na formação do indivíduo: ensaio de análise de uma função em psicologia. ( JORGE, Marco Antônio Coutinho; JUNIOR, Potiguara Mendes da Silveira, trad) 2a ed. Rio de Janeiro: Jorge Zahar, 2008b (Trabalho original publicado em 1984)

. Passagem ao ato e acting out. In: O Seminário, livro 10: a angústia. (RIBEIRO, Vera, trad). Rio de Janeiro: Zahar, 2005a. (Trabalho original publicado em 1962-1963)

. O simbólico, o imaginário e o real. In: Nomes-dopai. (TELLES, André, trad). Rio de Janeiro: Zahar, $2005 \mathrm{~b}$. 
. Proposição de 9 de outubro de 1967 sobre o psicanalista na Escola. In:

Outros Escritos. (RIBEIRO, Vera, trad). Rio de Janeiro: Zahar, 2003. (Trabalho original publicado em 2001)

- O estádio do espelho como formador da função do eu. In: Escritos. (RIBEIRO, Vera, trad). Rio de Janeiro: Zahar, 1998a (Trabalho original publicado em 1966) . O tempo lógico e a asserção de certeza antecipada: Um novo sofisma. In: Escritos. (RIBEIRO, Vera, trad). Rio de Janeiro: Zahar, 1998b (Trabalho original publicado em 1966)

LACADÉE, Philippe. A clínica da língua e do ato nos adolescentes. Tradução de Vilela Yolanda. Responsabilidades. Belo Horizonte, v. 1, n.2, p. 253-268, set. 2011/fev. 2012 Disponível em https://bit.ly/2pFBp7b Acesso em 22.Jan. 2018 LAGO, Mara Coelho de Souza. A psicanálise nas ondas dos feminismos. In C. Rial \& J. M. Pedro (Eds.), Diversidades: Dimensões de gênero e sexualidade (pp. 1-23). Disponível em https://bit.ly/2O42VJ3 Acesso em 22.Setembro.2018

LAPLANCHE, Jean. Vocabulário de psicanálise, Laplanche e Pontalis. (LAGACHE, Daniel, trad). São Paulo: Martins Fontes, 2004 (Trabalho originalmente publicado em 1982)

LAUREANO, Marcela Marjory Massolini. A interpretação (revelar e esconder sentidos): articulações entre análise do discurso e psicanálise lacaniana. Tese de Doutorado, Programa de Pós-Graduação em Psicologia, FFCLRP, USP, Ribeirão Preto, 2008.

LÉVI-STRAUSS, Claude. O problema do incesto. In: As estruturas elementares do parentesco. (FERREIRA, Mariano. trad). 7a ed. Petrópolis: Vozes, 2012 (Trabalho original publicado em 1967)

LISPECTOR, Clarice. Começos de uma fortuna. In: . Laços de família. Roccodigital, 1998. Disponível em https://bit.ly/2pUCpnH Acesso em 15.Out. 2018

MORLEY, Helena. Domingo, 17 de fevereiro. In: .Minha vida de menina. Companhia de Bolso, 2016. Disponível em <encurtador.com.br/fntF7> Acesso em Acesso em 16. Jul. 2019

MRECH, Leny Magalhães. Mas, afinal o que é educar? In: (org). O impacto da psicanálise na educação. São Paulo: Avercamp editora, 2005a 
. Os impactos do Terceiro ensino de Lacan: novas contribuições para

algumas articulações possíveis entre Psicanálise e Educação. In: (org). $\mathbf{O}$ impacto da psicanálise na educação. São Paulo: Avercamp editora, 2005b

NASSAR, Raduan. Lavoura Arcaica. In: Obra completa. São Paulo: Companhia das letras, 2016

NÁSIO, Juan-David. Os olhos de Laura: Somos todos loucos em algum recanto de nossas vidas. (BERLINER, Claúdia, trad). Rio de Janeiro: Zahar, 2011 (Trabalho original publicado em 1987)

Édipo: O complexo do qual nenhuma criança escapa. (TELLES, André, trad). Rio de Janeiro: Zahar, 2007 (Trabalho original publicado em 2005)

. Como trabalha um psicanalista? (MAGALHÃES, Lucy, trad). Rio de Janeiro: Zahar, 1999.

O Conceito de IDENTIFICAÇÃO. In: Lições sobre os 7 conceitos cruciais da psicanálise. (RIBEIRO, Vera, trad). Rio de Janeiro: Jorge Zahar, 1989. (Trabalho original publicado em 1988)

ORLANDI, Eni P. Análise De Discurso: Princípios e Procedimentos. Campinas: Pontes, 2015

PEDROZA, Regina Lúcia Sucupira. Psicanálise e educação: análise das práticas pedagógicas e formação do professor. Psicol. educ., São Paulo, n. 30, p. 81-96, jun., 2010 Disponível em https://bit.ly/2vBzNhP Acesso em 10.Agosto. 2018

PÊCHEUX, Michel. O Discurso: estrutura ou acontecimento. (ORLANDI, Eni Puccinelli, trad) 7a ed. Campinas: Pontes, 2015 (Trabalho originalmente publicado em 1983)

PEREIRA, Rodrigo da Cunha. Direito de família: Uma abordagem psicanalítica. Rio de Janeiro: Editora Forense, 2012

PEREIRA, Marcelo Ricardo. Subversão docente: ou para além da "realidade do aluno". In: MRECH, Leny Magalhães (org). O impacto da psicanálise na educação. São Paulo: Avercamp editora, 2005

QUINET, Antônio. Prefácio: Ex-tranha. In: A estranheza da psicanálise: A escola de Lacan e seus analistas. Rio de Janeiro: Zahar, 2009. 
RAMON, Fabíola; MOREL, Kátila Kormman; MENDONÇA, Ricardo Coimbra de; PARAVIDINI, Roberta Augusta Borges; PAIXÃO, Christiana Coimbra; NOBRE, Sabrina Ribeiro. Impasses no Contemporâneo: Para uma psicanálise implicada com seu tempo. Entrevários. Número 16, Novembro, 2016, pp. 99-104

REZENDE, Ana Paula F.; FEITAS, Ceres Leda F.; AFONSO, Luene; VIEIRA, Geanine Lucas; CARNEIRO, Suraia O. Veloso. Família, Criança e Sinthoma. Nova Rede Cereda Brasil, Folha dos Núcleos. Número 40, 2017, pp. 24-28

ROSA, Miriam Debieux. Histórias que não se contam: o não-dito na psicanálise com crianças e adolescentes. 2 ed. São Paulo: Casa do Psicólogo, 2009

A pesquisa psicanalítica dos fenômenos sociais e políticos: metodologia e fundamentação teórica. Revista Mal-estar e subjetividade. 4(2) 329-348, 2004. Disponível em https://bit.ly/2PyOkTX Acesso em 25.Agosto.2018

ROSA, Miriam Debieux, DOMINGUES, Eliane. O método na pesquisa psicanálitica de fenômenos sociais e políticos: a utilização da entrevista e da observação. Psicologia e Sociedade 22 (1), 180-188, 2010. Disponível em https://bit.ly/2P43krW Acesso em 25. Agosto. 2018

ROSA, Miriam Debieux; VICENTIN, Maria Cristina. Os intratáveis: o exílio do adolescente do laço social pelas noções de periculosidade e irrecuperalidade. Psicologia Política. Vol. 10. $\mathrm{n}$ 19. pp. 107-124. JAN. -JUN. 2010. Disponível em https://bit.ly/2I5kfXH . Acesso em: 19. Jan. 2018.

ROUDINESCO, Élisabeth. A família em desordem. (TELLES, André, trad) 1a ed. Rio de Janeiro: Zahar, 2003 (Trabalho originalmente publicado em 2002).

ROUDINESCO, Élisabeth; PLON, Michel. Dicionário de Psicanalise. (RIBEIRO, Vera; MAGALHÃES, Lucy; trad). Rio de Janeiro: Zahar, 1998 (Trabalho originalmente publicado em 1997).

SOLER, Colette. O que faz laço? (SAPORITI, Elisabeth, trad). São Paulo: Escuta, 2016 (Trabalho original publicado em 2011)

VITORELLO, Márcia Aparecida. Família contemporânea e as funções parentais: há nela um ato amor?. Psicologia da Educação, (32), 7-24, 2011 Disponível em https://bit.ly/2MnWbVO Acesso em 10.Agosto. 2018 
VOLTOLINI, Rinaldo. Educação e Psicanálise. Rio de Janeiro: Zahar, 2011 


\section{ANEXO I}

\section{Termo de Consentimento Livre e Esclarecido}

1.Seu tutelado está sendo convidado para participar da pesquisa "Os discursos sobre laços de família e escola: o que os estudantes tem a dizer?"

2.Solicita-se o seu consentimento para seu tutelado participar de uma entrevista sobre o tema que será gravada e posteriormente transcrita.

3.A qualquer momento você pode desistir e retirar seu consentimento.

4.Sua recusa não trará nenhum prejuízo em sua relação com a pesquisadora.

5.Assegura-se o sigilo sobre a identidade da participação de seu tutelado, ou seja, o nome dele não será divulgado nas apresentações dos resultados.

6.Os benefícios relacionados da participação dele serão de poder contribuir para o desenvolvimento de conhecimento a respeito da questões familiares na atualidade e a relação com a escola.

7.O risco relacionado com participação dele é de, por alguma intercorrência, o sigilo for rompido e haver algum tipo de constrangimento. Comprometo-me a retirar os dados de seu tutelado da pesquisa caso alguma intercorrência ocorra.

8.Você receberá uma cópia deste termo onde consta o telefone e o endereço da pesquisadora principal, podendo tirar suas dúvidas sobre o projeto e sua participação, agora ou a qualquer momento.

\section{Dayana Coelho Souza}

16 981395555, Rua Antônio Gual, 204, CEP: 14051-320, Sumarezinho, Ribeirão Preto, SP

Declaro que entendi os objetivos, riscos e benefícios da participação de meu tutelado na pesquisa e concordo que ele participe.

A pesquisadora me informou que o projeto foi aprovado pelo CEP - Comitê de Ética em Pesquisa da FFCLRP USP localizado na Avenida Bandeirantes, 3900 - Bloco 01 - Sala 7 Prédio da Administração FFCLRP/USP 14040-901 - Ribeirão Preto - SP - Brasil, Fone: (16) 3315-4811/ Atendimento de 2a a 6a das $13 \mathrm{h30}$ às 17h30/ E-mail: coetp@ffclrp.usp.br / homepage: http://www.ffclrp.usp.br 


\section{ANEXO II}

\section{Termo de Assentimento}

1.Você está sendo convidado para participar da pesquisa "Os discursos sobre laços de família e escola: o que os estudantes tem a dizer?"

2.Solicita-se a sua concordância para participar de uma entrevista sobre o tema que será gravada e posteriormente transcrita.

3.A qualquer momento você pode desistir e retirar concordância.

4.Sua recusa não trará nenhum prejuízo em sua relação com a pesquisadora.

5.Assegura-se o sigilo sobre sua identidade, ou seja, seu nome não será divulgado nas apresentações dos resultados.

6.Os benefícios relacionados da sua participação serão de poder contribuir para o desenvolvimento de conhecimento a respeito da questões familiares na atualidade e a relação com a escola.

7.O risco relacionado a sua participação é de, por algum acidente, o sigilo for rompido e haver algum tipo de constrangimento. Comprometo-me a retirar seus dados da pesquisa caso algum acidente ocorra.

8.Você receberá uma cópia deste termo onde consta o telefone e o endereço da pesquisadora principal, podendo tirar suas dúvidas sobre o projeto e sua participação, agora ou a qualquer momento.

\section{Dayana Coelho Souza}

16 981395555, Rua Antônio Gual, 204, CEP: 14051-320, Sumarezinho, Ribeirão Preto, SP

Declaro que entendi os objetivos, riscos e benefícios da minha participação na pesquisa e concordo com a minha participação.

A pesquisadora me informou que o projeto foi aprovado pelo CEP - Comitê de Ética em Pesquisa da FFCLRP USP localizado na Avenida Bandeirantes, 3900 - Bloco 01 - Sala 7 Prédio da Administração FFCLRP/USP 14040-901 - Ribeirão Preto - SP - Brasil, Fone: (16) 3315-4811/ Atendimento de 2a a 6a das $13 \mathrm{h30}$ às 17h30/ E-mail: coetp@ffclrp.usp.br / homepage: http://www.ffclrp.usp.br 


\section{ANEXO III}

\section{ROTEIRO DE ENTREVISTA}

-Informações básicas

Idade:

Gênero:

Série que frequenta:

-Roteiro

1) Quem mora na sua casa?

2) O que vocês costumam fazer juntos?

3) Quem você considera sua família?

4) O que vocês costumam fazer juntos?

5) Você sabe como sua família se formou? Se sim, poderia contar a história da sua família?

6) Se houver pessoas consideradas família que não mora com ele/a: Você costuma conviver com a pessoa?

7) Se houver pessoas consideradas família que não mora com ele/a: O que vocês costumam fazer juntos?

8) Se houver pessoas consideradas família que não mora com ele/a: Se não convivem, por que acha que isso acontece?

9) Quem da sua família você acha que tem uma melhor convivência com você? Por que você considera essa convivência melhor?

10) Desde quando é assim?

11) Quem da sua família você acha que tem uma convivência ruim com você? Por que você considera essa convivência ruim?

12) Desde quando é assim?

13) O que é família para você?

14) Para que ela serve?

15) Você acha que as famílias do passado são diferentes das atuais famílias? Por que?

16) O que é a escola para você?

17) Para que ela serve?

18) Você acha que escola e família possuem alguma coisa em comum, alguma coisa parecida?

19) Se sim, o que? 